\title{
Synthesis of zero-valent iron/biochar by carbothermal reduction from wood waste and iron mud for removing rhodamine $B$
}

Chao Chen ( $\nabla$ cchao1990@163.com )

Tsinghua University https://orcid.org/0000-0001-9127-9630

Jianguo Liu

Tsinghua University

Chao Gen

Tsinghua University

Qin Liu

Tsinghua University

Xuetao Zhu

Tsinghua University

Wenzhi Qi

Tsinghua University

\section{Fan Wang}

Tsinghua University

\section{Research Article}

Keywords: Wood waste, Iron mud, Carbothermal reduction, zero-valent iron/biochar, Rhodamine B

Posted Date: March 16th, 2021

DOl: https://doi.org/10.21203/rs.3.rs-158094/v1

License: (9) (i) This work is licensed under a Creative Commons Attribution 4.0 International License.

Read Full License 
3 Chao Chen, Jianguo Liu*, Chao Gen, Qin Liu, Xuetao Zhu, Wenzhi Qi, Fan Wang

4 School of Environment, Tsinghua University, Beijing 100084, China

$5 \bowtie$ jgliu@tsinghua.edu.cn

6 GRAPHICAL ABSTRACT

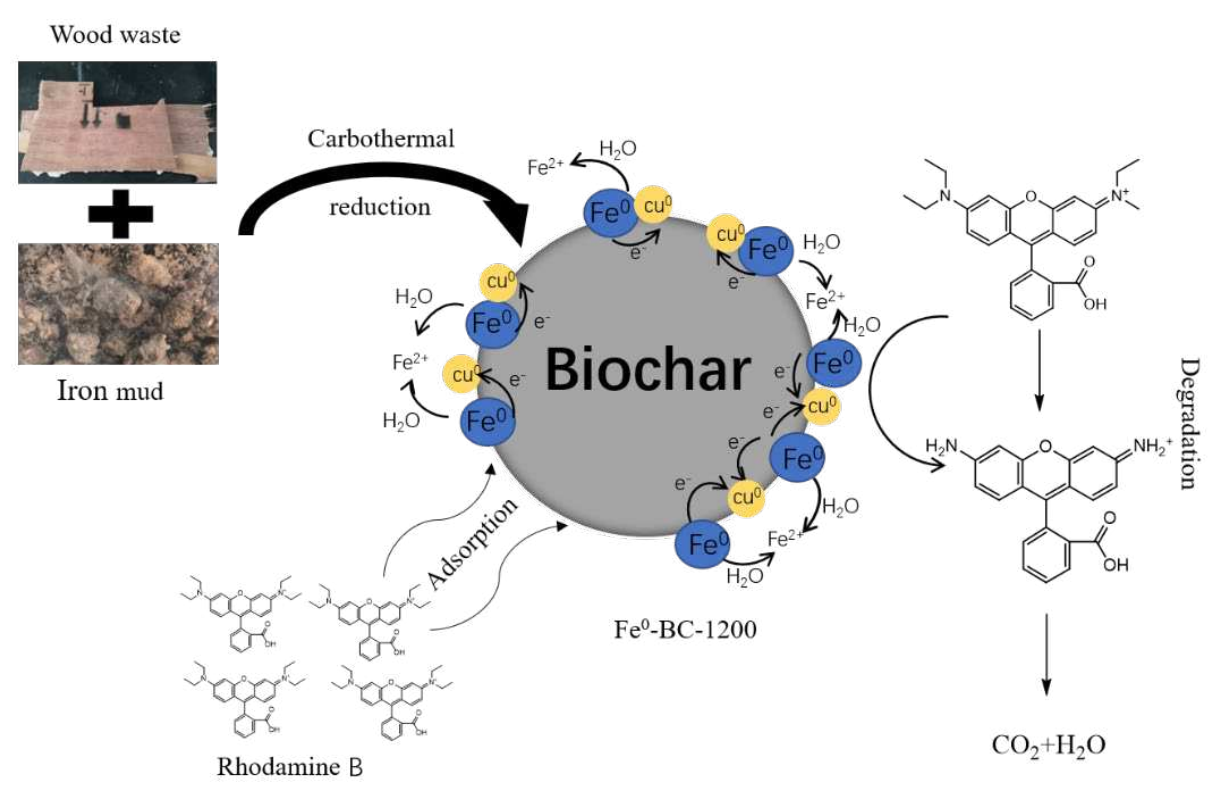

\begin{abstract}
This study proposes a new process to synthesize zero-valent iron/biochar $\left(\mathrm{Fe}^{0}-\mathrm{BC}\right)$ by carbothermal reduction using wood waste and iron mud as raw materials under different temperature. The characterization results showed that the $\mathrm{Fe}^{0}-\mathrm{BC}$ synthesized at $1200^{\circ} \mathrm{C}$ $\left(\mathrm{Fe}^{0}-\mathrm{BC}-1200\right)$ possessed favorable adsorption capacity with the specific surface area of $103.18 \mathrm{~m}^{2} / \mathrm{g}$, and that the zero-valent iron $\left(\mathrm{Fe}^{0}\right)$ particles were uniformly dispersed on the biochar surface. The removal efficiency of rhodamine $\mathrm{B}(\mathrm{RB})$ was determined to evaluate the performance of the prepared $\mathrm{Fe}^{0}-\mathrm{BC}$. $\mathrm{Fe}^{0}-\mathrm{BC}-1200$ presented the best performance on $\mathrm{RB}$ removal, which mainly ascribe to that more $\mathrm{Fe}^{0}$ particles generated at higher temperature. The equilibrium adsorption capacity reached $49.93 \mathrm{mg} / \mathrm{g}$ when the initial RB concentration and the $\mathrm{Fe}^{0}-\mathrm{BC}-1200$ dosage were $100 \mathrm{mg} / \mathrm{L}$ and $2 \mathrm{~g} / \mathrm{L}$, respectively, and the pseudo-second-order model was suitable to fit the removal experimental data. LCMC and XRD analyses revealed that the removal mechanism included the physical adsorption of biochar and the redox reaction of $\mathrm{Fe}^{0}$. Moreover, copper existed in the iron mud was also reduced to $\mathrm{Cu}^{0}$, which was beneficial to catalyze the oxidation of iron, the degradation of RB was promoted at the same time.
\end{abstract}

Keywords: Wood waste; Iron mud; Carbothermal reduction; zero-valent iron/biochar; Rhodamine B. 
In recent years, with the rapid growth in the living standard in China, the life cycle of many furniture is becoming shorter and shorter, and frequent housing rental activities increase the probability of wood waste being abandoned. According to statistics, about 85 million $\mathrm{m}^{3}$ of bulky wood waste are produced every year in China. The main component of wood waste is wood, and the carbon content is between $40 \%$ and $50 \%$ (Emandi et al., 2011; Tsoumis, 2013; Demirbaş, 2005). Thus, preparing biochar by pyrolysis of wood waste is one of the effective recycling methods. Biochar shows outstanding potential for removing organic contaminants from the environment by possessing abundant oxygen-containing functional groups and large surface area (Liu et al., 2015; Zhang et al., 2019; Huang et al., 2018; Wang et al., 2018). However, the application of biochar in wastewater has some problems, such as difficult separation and incomplete removal (Chen et al., 2011; Du et al., 2020). To overcome these shortcomings, many researchers loaded zero-valent iron $\left(\mathrm{Fe}^{0}\right)$ on biochar surface to excellent environmental remediation material has been widely used in wastewater and contaminated soil treatment due to its high reducibility for heavy metals and organic matter (Pourrezaei et al., 2014; Reddy et al.,2016; Calderon and Fullana 2015; Ghariani et al., 2019). As a combination, $\mathrm{Fe}^{0}-\mathrm{BC}$ has the advantages of both biochar and $\mathrm{Fe}^{0}$, thereby it provides higher reduction or degradation efficiency and other benefits including easiness to recycle, non- aggregation. (Bakshi et al., 2018; Li et al.,2020; Dong et al., 2017; Li et al., 2019;). More and more studies proved that $\mathrm{Fe}^{0}-\mathrm{BC}$ show better performance in removing different contaminants through reduction, adsorption, precipitation and other mechanisms (Frick et al.,2016; Oh et al., 2016; Oleszczuk and Kołtowski 2017; Mitzia et al.,2020).

In order to obtained the more valuable $\mathrm{Fe}^{0}-\mathrm{BC}$, the other solid waste, iron mud could be used as an iron resource for collaborative utilization with wood waste. Iron mud refers to the waste slag with high iron content produced in chemical industrial production, such as dyeing and printing enterprises (Pani et al., 2019; Liu et al., 2018). The iron mud mainly contains iron oxide and organic compounds that can be recovered (Zhu et al., 2018). At present, iron mud is usually disposed by stacking, landfilling, or sending to steel plants as a raw material of iron-making in China (Liu et al., 2014). The stacking and landfilling of iron mud take up massive land, and the existing hazardous substances permeate into the underground, causing secondary pollution to the environment. For sending to steel plant, iron mud can easily block the furnace because of its fine particle size, thereby seriously reducing the product quality and complicating the recycling process.

At present, the most used widely synthesis method is the two-step method (Devi et al., 2014; Liu et al., 2015; Zhao et al., 2020; Han et al., 2019; Sun et al., 2019; Dewage et al., 2018), which refer to that the biomass is pyrolyzed to obtain biochar firstly, then strongly impregnated in the high valent iron salts, and then reduced through liquid- 
phase or gas-phase reductant. Devi et al. (2014) synthesized $\mathrm{Fe}^{0} / \mathrm{BC}$ composites from the paper mill sludge through the following process: paper mill sludge was pyrolyzed to biochar at $700{ }^{\circ} \mathrm{C}$, mixed with $\mathrm{FeSO}_{4} \cdot \mathrm{H}_{2} \mathrm{O}$, and then added $\mathrm{NaBH}_{4}$ as a reducing agent for the reduction of $\mathrm{Fe}^{2+}$ to $\mathrm{Fe}^{0}$ at the same time. Liu et al. (2015) obtained $\mathrm{Fe}^{0} / \mathrm{BC}$ by the reduction of natural limonite and pine biomass using $\mathrm{H}_{2}$ at $550^{\circ} \mathrm{C}$. The above synthesis process needs a large number of reducing reagents, with high raw material cost and complex operation, thus, it can only be applied to laboratory research. Carbothermal reduction is another synthesis method (Lawrinenko et al., 2017; Mandal et al., 2017; Hussain et al., 2017), in which iron compounds and biomass are mixed to pyrolysis at a high temperature, the iron compounds are reduced by the reducing substances generated during biomass pyrolysis, and then $\mathrm{Fe}^{0} / \mathrm{BC}$ is prepared by one step. Lawrinenko et al. (2017) successfully prepared $\mathrm{Fe}^{0} / \mathrm{BC}$ through the slow pyrolysis of lignin and magnetite mixtures in a muffle furnace and heated at $900{ }^{\circ} \mathrm{C}$ for $4 \mathrm{~h}$. By contrast, carbothermal reduction has the advantages of low raw material cost, simple process, easy scaling, continuous production (Shang et al., 207).

Rhodamine $\mathrm{B}(\mathrm{RB}), \mathrm{C}_{28} \mathrm{H}_{31} \mathrm{~N}_{2} \mathrm{O}_{3} \mathrm{Cl}$, a highly water-soluble and bright red fluorescent xanthene dye, is widely used as colorant for textiles and food industry (Long et al., 2014). However, it has been proven that RB has toxic effects on animals and humans, including carcinogenicity, reproductive toxicity and neurotoxicity (Dong et al., 2010). $\mathrm{RB}$ is a ubiquitous organic pollutant in printing and dyeing wastewater due to the wide application in the textile industry (Lops et al., 2019; Huang et al., 2017). Therefore, it has great significance to find a suitable process or material to remove the RB in wastewater.

The massive production and stacking of wood waste and iron mud engenders a serious environmental pollution and waste of resources. To overcome these problems, in this study, a novel process, wood waste and iron mud were used as raw materials, to synthetize $\mathrm{Fe}^{0}$ - $\mathrm{BC}$ through carbothermal reduction, was proposed. At the same time, the removal efficiency of $\mathrm{RB}$ was conducted to evaluate the performance of synthetic $\mathrm{Fe}^{0}$-BC. The structural composition and micromorphology of synthetic $\mathrm{Fe}^{0}-\mathrm{BC}$ was investigated. Moreover, the interaction process between the $\mathrm{Fe}^{0}-\mathrm{BC}$ and $\mathrm{RB}$ was also studied.

\section{Materials and Methods}

\section{Materials}

The iron mud used in this study was obtained from a printing and dyeing factory in Shanghai, China. The chemical compositions of iron mud measured by X-ray fluorescence spectrometry (XRF) is shown in Table 1, and the X-ray diffraction (XRD) pattern of the iron mud is presented in Figure 1. The results show that the iron mud contain $41.71 \% \mathrm{Fe}_{2} \mathrm{O}_{3}, 15.23 \% \mathrm{CuO}$, and $10.12 \% \mathrm{C}$, and the main phases are magnetite $\left(\mathrm{Fe}_{3} \mathrm{O}_{4}\right)$, Tenorite $(\mathrm{CuO})$, organic iron $\left(\mathrm{Fe}_{2} \mathrm{C}_{6} \mathrm{H}_{10} \mathrm{O}_{4}\right)$ and calcium aluminosilicate. Wood 
waste used in this study was abandoned wooden chair from the laboratory. The chair is made of pine wood board and is not painted. The carbon content of the chair is $43.14 \%$, which was measured by Elemental Analyzer (FlashSmart, Thermo, American).

All chemical reagents are analytically pure, and ultrapure water was used throughout this study.

Table1 Chemical compositions of the iron mud

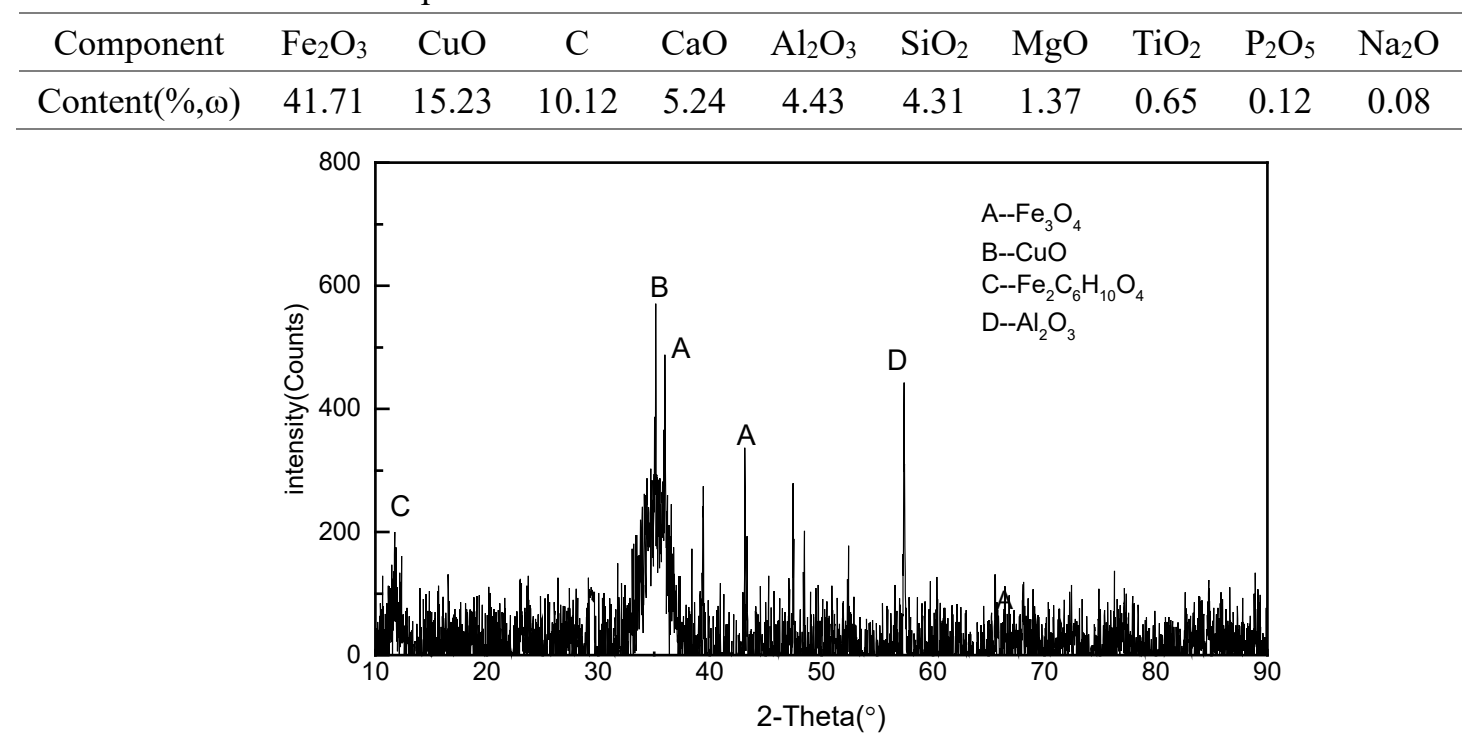

Figure 1. XRD patterns of the iron mud

\section{Synthesis of $\mathrm{Fe}^{0}-\mathrm{BC}$}

According to our previous related works (Geng et al.,2020; Chen et al.,2019), $\mathrm{Fe}^{0}$-BC was prepared as shown in Figure 2. Firstly, the wooden chair and iron mud were dried in an oven for $2 \mathrm{~h}$ at $110{ }^{\circ} \mathrm{C}$ after cleaning, and then the wood flour was prepared by crushing in a crusher and passing through a 40-mesh sieve. Additionally, the wood flour and dried iron mud with a mass ratio of 1:2 were homogeneously mixed using a $150 \mathrm{r} / \mathrm{min}$ roller mill for $5 \mathrm{~min}$, and then a $40 \mathrm{~g}$ mixture was placed into a corundum crucible. Subsequently. carbothermal reduction of the mixture was conducted by heating under nitrogen in a sealed furnace at $800^{\circ} \mathrm{C}, 900{ }^{\circ} \mathrm{C}, 1000^{\circ} \mathrm{C}, 1100{ }^{\circ} \mathrm{C}, 1200^{\circ} \mathrm{C}$, respectively. The furnace temperature was increased at an average of $15^{\circ} \mathrm{C} / \mathrm{min}$, and a 180 min holding time was applied when the temperature reached the target temperature. After roasting, the reduced product was taken out when self-cooled down to laboratory temperature. Finally, $\mathrm{Fe}^{0}-\mathrm{BC}$ was prepared by grinding in a $200 \mathrm{r} / \mathrm{min}$ rod mill for $10 \mathrm{~min}$ and passing through a 200-mesh sieve, named as $\mathrm{Fe}^{0}$-BC-T, where $\mathrm{T}$ indicates the carbothermal reduction temperature. The synthesis process was repeated three times at each temperature. The subsequent experimental data used for plotting graphs is the average value of three experimental data.

After synthesis of $\mathrm{Fe}^{0}$-BC-T, some samples were cleaned repeatedly using $2 \mathrm{~mol} / \mathrm{L}$ $\mathrm{HCl}$ until no change in weight after drying. And then the biochar without Fe was obtained, named as BC-T. 


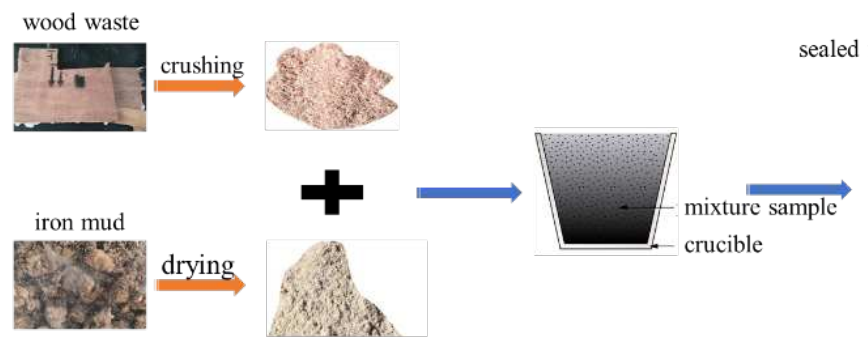

Mixing

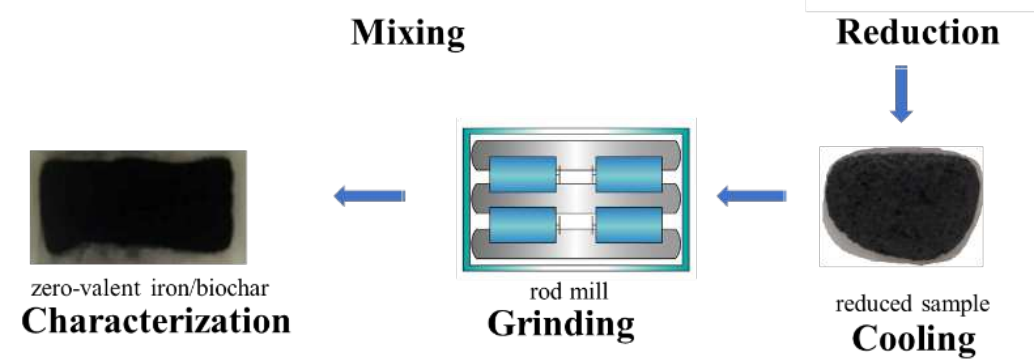

Figure 2. The preparation process of $\mathrm{Fe}^{0}-\mathrm{BC}$

\section{6}

137

138

139

140

141

142

\section{3}

144

145

146

147

148

149

150

151

152

153

154

155

\section{Characterizations}

The pore-structure parameters were measured by specific surface area and porosity analyzer (ASAP2010, Micromeritics, American) using $\mathrm{N}_{2}$ adsorption method. The phase composition present in the samples was detected by XRD (D/max-2550, Rigaku, Japan) with $\mathrm{Cu} K_{\alpha}$ radiation over a $2 \theta$ collection range of $10^{\circ} \sim 90^{\circ}$. Micromorphology was analyzed by scanning electron microscope (SEM), and energy dispersive spectrometry (EDS) ((JSM-6460LV, JEOL, Japan).

\section{Removal experiments}

The removal efficiency of RB on different materials was investigated, including the $\mathrm{Fe}^{0}-\mathrm{BC}-\mathrm{T}, \mathrm{BC}-\mathrm{T}$ and the purchased $\mathrm{Fe}^{0}$ powder.1.6 $\mathrm{g}$ of each material $(2 \mathrm{~g} / \mathrm{L})$ was added into a $1000 \mathrm{~mL}$ conical flask with $800 \mathrm{~mL}$ RB solution with an initial concentration of $100 \mathrm{mg} / \mathrm{L}$ and an initial $\mathrm{pH}$ ranging from 1.5 to 6 . The $\mathrm{pH}$ of the prepared $100 \mathrm{~mol} / \mathrm{L} \mathrm{RB}$ solution is 4.02 . The target initial $\mathrm{pH}$ value of solution was adjusted by diluted $\mathrm{HCl}$ or $\mathrm{NaOH}$. The conical flasks were placed in a $60 \mathrm{r} / \mathrm{min}$ shaker at $25^{\circ} \mathrm{C}$, and $5 \mathrm{ml}$ of suspension extracted from flask was filtered with a $0.45 \mu \mathrm{m}$ microporous filtration membrane at predetermined time intervals. Meanwhile, the solution $\mathrm{pH}$ value was recorded during the whole removal process. The residual RB concentrations were evaluated by ultraviolet and visible spectrophotometry (UV-Vis) (5B-3B, Lian-hua, China). RB removal capacity and removal efficiency can be obtained by Eq. (1) and Eq. (2), respectively.

$$
\begin{gathered}
q_{e}=\frac{C_{0}-C_{e}}{m} V \\
R=\frac{C_{0}-C_{t}}{C_{0}} \times 100
\end{gathered}
$$


Where $q_{e}, R, m, V$ stand for the RB removal capacity $(\mathrm{mg} / \mathrm{g})$, removal efficiency (\%), RB solution volume (L), and the dose (g) of materials. $C_{0}, C_{e}, C_{t}$ stand for initial concentration $(\mathrm{mg} / \mathrm{L})$, equilibrium concentration $(\mathrm{mg} / \mathrm{L})$ and residual concentration $(\mathrm{mg} / \mathrm{L})$ at time $\mathrm{t}(\mathrm{min})$.

Adsorption kinetic of removal process was evaluated by pseudo-first order and pseudo-second-order models, as shown in Eq. (5) and Eq. (6) respectively.

$$
\begin{gathered}
\ln \left(q_{e}-q_{t}\right)=\ln q_{e}-k_{1} t \\
\frac{t}{q_{t}}=\frac{1}{k_{2} q_{e}^{2}}+\frac{t}{q_{e}}
\end{gathered}
$$

where $k_{1}\left(\mathrm{~min}^{-1}\right)$ and $k_{2}(\mathrm{~g} /(\mathrm{mg} \cdot \mathrm{min}))$ stand for the sorption rate constants of quasifirst order and quasi-second order, respectively; $q_{e}(\mathrm{mg} / \mathrm{g})$ represent the removal capacities at the equilibrium; $q_{t}(\mathrm{mg} / \mathrm{g})$ represent the removal capacities at the time $\mathrm{t}$ (min).

Reaction products at different times were measured by LCMS (1290II-6460, Agilent, American) under the following conditions: chromatographic column of XDB-C8 $4.6^{*} 150 \mathrm{~mm}, 5 \mu \mathrm{m}$, column temperature of $50^{\circ} \mathrm{C}$, mobile phase of methanol-water (70:30), test time of $30 \mathrm{~min}$, and flow rate of $0.8 \mathrm{~mL} / \mathrm{min}$.

\section{Results and discussion}

\section{Characterization of $\mathrm{Fe}^{\mathbf{0}}$-BC}

The XRD analysis results of $\mathrm{Fe}^{0}$-BC prepared at different temperature are shown in Figure 3. The main phases of $\mathrm{Fe}^{0}-\mathrm{BC}-800$ and $\mathrm{Fe}^{0}-\mathrm{BC}-900$ are both $\mathrm{Fe}_{3} \mathrm{O}_{4}$ and $\mathrm{CuO}$. This finding indicated that the organic iron in the mixture were pyrolyzed to $\mathrm{Fe}_{3} \mathrm{O}_{4}$, whereas the iron oxide was not reduced under $900{ }^{\circ} \mathrm{C}$. The diffraction peaks of $\mathrm{CuO}$ disappeared and the diffraction peaks of zero valent copper $\left(\mathrm{Cu}^{0}\right)$ were observed in the XRD pattern of $\mathrm{Fe}^{0}-\mathrm{BC}-1000$, which confirmed that $\mathrm{CuO}$ was reduced by the reducibility of pyrolysis products such as $\mathrm{C}, \mathrm{CO}, \mathrm{H}_{2}$, as shown in Eq. (3). When the reduced temperature reached $1100{ }^{\circ} \mathrm{C}$, the diffraction peaks of zero valent iron $\left(\mathrm{Fe}^{0}\right)$ appeared and the diffraction peaks of $\mathrm{Fe}_{3} \mathrm{O}_{4}$ weakened, proving that part of $\mathrm{Fe}_{3} \mathrm{O}_{4}$ was reduced via Eq. (4) at this temperature (Chen et al., 2017). The main phases of $\mathrm{Fe}^{0}$-BC1200 are $\mathrm{Fe}^{0}$ and $\mathrm{Cu}^{0}$, and the iron oxide in the mixture competely reduced to $\mathrm{Fe}^{0}$ at $1200{ }^{\circ} \mathrm{C}$.

$$
\begin{gathered}
\mathrm{CuO}+\mathrm{C} / \mathrm{CO} / \mathrm{H}_{2} \longrightarrow \mathrm{Cu}+\mathrm{CO} / \mathrm{CO}_{2} / \mathrm{H}_{2} \mathrm{O} \\
\mathrm{Fe}_{3} \mathrm{O}_{4}+4 \mathrm{C} / \mathrm{CO} / \mathrm{H}_{2} \longrightarrow 3 \mathrm{Fe}+4 \mathrm{CO} / \mathrm{CO}_{2} / \mathrm{H}_{2} \mathrm{O}
\end{gathered}
$$




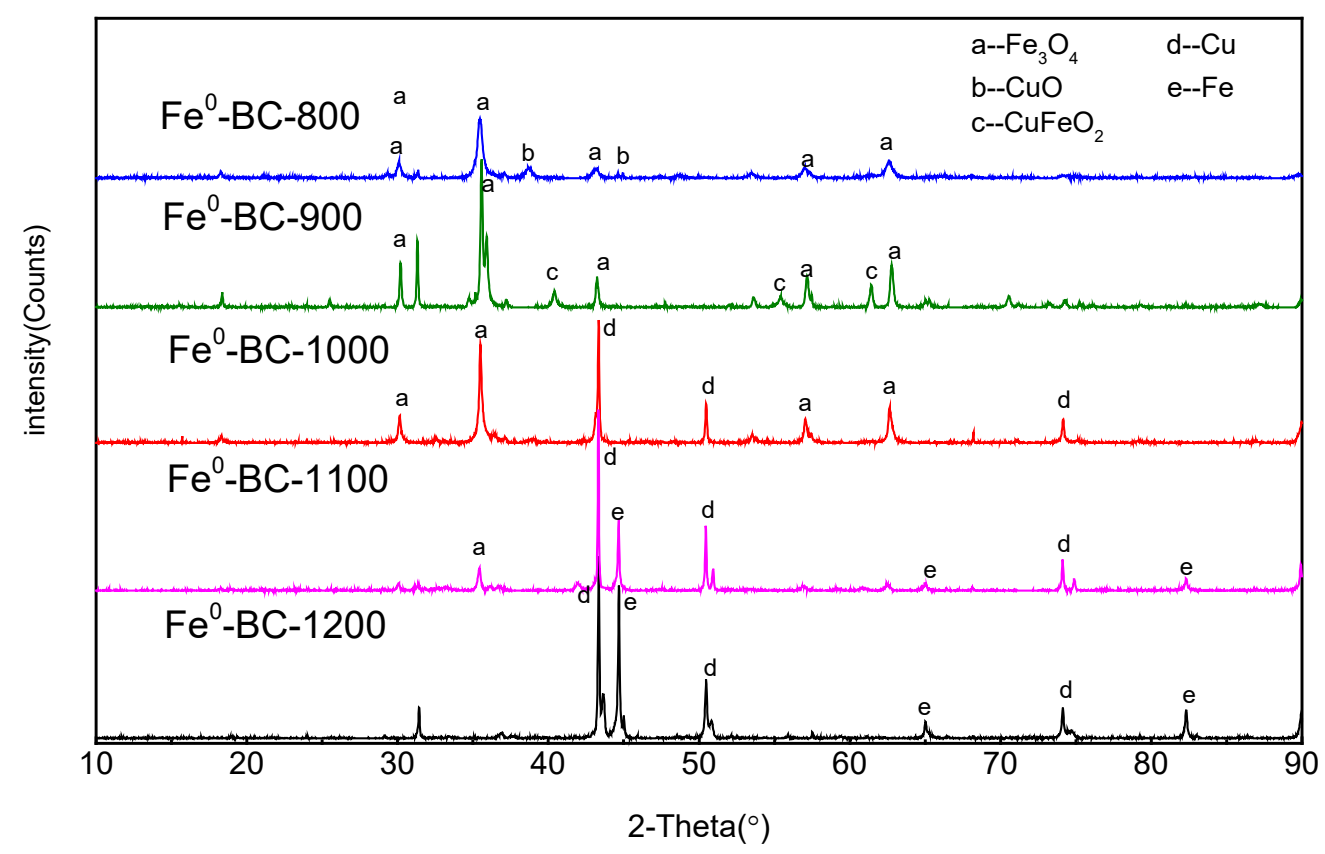

184

185

186

187

188

189

190

191

192

193

194

195

196

197

Figure 3. XRD patterns of $\mathrm{Fe}^{0}-\mathrm{BC}$

Table 2 shows the main element composition of different $\mathrm{Fe}^{0}-\mathrm{BC}$ materials. As shown in Table 2, the content of $\mathrm{C}$ was higher than those of $\mathrm{Fe}$ and $\mathrm{Cu}$, and the content of $\mathrm{Fe}$ and $\mathrm{Cu}$ increased with the increase of temperature. This result can be ascribed to the fact that the increase of temperature is conducive to the reduction of iron and copper compounds. Thus, the carbon reductant was consumed at a high temperature. The surface area and pore size of $\mathrm{Fe}^{0}-\mathrm{BC}$ are shown in Table 3. It can be seen that the $\mathrm{Fe}^{0}$ $\mathrm{BC}$ have similar properties in pore structure with the specific surface area is about 100 $\mathrm{m}^{2} / \mathrm{g}$ and a pore size between 3 and $4 \mathrm{~nm}$, indicating favorable adsorption performance to some extent.

Table 2 Main element contents of $\mathrm{Fe}^{0}-\mathrm{BC}$

\begin{tabular}{cccc}
\hline Element & $\mathrm{Fe}$ & $\mathrm{C}$ & $\mathrm{Cu}$ \\
\hline $\mathrm{Fe}^{0}-\mathrm{BC}-800$ & 23.8 & 44.2 & 16.6 \\
\hline $\mathrm{Fe}^{0}-\mathrm{BC}-900$ & 23.6 & 43.3 & 16.9 \\
\hline $\mathrm{Fe}^{0}-\mathrm{BC}-1000$ & 26.7 & 40.7 & 17.8 \\
\hline $\mathrm{Fe}^{0}-\mathrm{BC}-1100$ & 27.2 & 37.4 & 17.6 \\
\hline $\mathrm{Fe}^{0}-\mathrm{BC}-1200$ & 31.2 & 34.3 & 20.4 \\
\hline
\end{tabular}

Table 3 The pore-structure parameters of Fe-C

\begin{tabular}{ccc}
\hline Sample & specific surface area $\left(\mathrm{m}^{2} / \mathrm{g}\right)$ & pore Diameter $(\mathrm{nm})$ \\
\hline $\mathrm{Fe}^{0}-\mathrm{BC}-800$ & 151.8 & 4.19 \\
\hline $\mathrm{Fe}^{0}-\mathrm{BC}-900$ & 143.6 & 3.32 \\
\hline $\mathrm{Fe}^{0}-\mathrm{BC}-1000$ & 116.7 & 3.35 \\
\hline $\mathrm{Fe}^{0}-\mathrm{BC}-1100$ & 97.2 & 4.21 \\
\hline $\mathrm{Fe}^{0}-\mathrm{BC}-1200$ & 103.18 & 3.69 \\
\hline
\end{tabular}

199 Consistent with previous studies (Kong et al., 2018; Geng et al., 2019; Shen et al., 
2019), the above results proved that the temperature of carbothermal reduction considerably influenced the phase of $\mathrm{Fe}$, and only $\mathrm{Fe}^{0}-\mathrm{BC}-1200$ existed no other ironcontaining phases aside from $\mathrm{Fe}^{0}$. SEM and EDS analyses were performed on $\mathrm{Fe}^{0}-\mathrm{BC}$ 1200, and the results are shown in Figure 4. As shown in Figure 4(a), the gray part of the picture was detected as biochar and the brighter dots were detected as $\mathrm{Fe}^{0}$. In addition, the $\mathrm{Fe}^{0}$ particles were appropriately dispersed on the granular biochar surface. Moreover, no aggregation of iron occurred, the size $\mathrm{Fe}^{0}$ particles of was $\mathrm{Fe}^{0}$ particle very small, basically approached nanometer level. A random section of biochar surface was selected for EDS analysis, and the result is presented in Figure 4(b). It illustrates that the $\mathrm{Cu}^{0}$ migrated to the biochar surface at the same time. In general, according to the previous study, the presence of $\mathrm{Cu}$ can form bimetals with $\mathrm{Fe}^{0}$, that is favor to accelerate the degradation of organic pollutants by catalyzing the corrosion of iron.

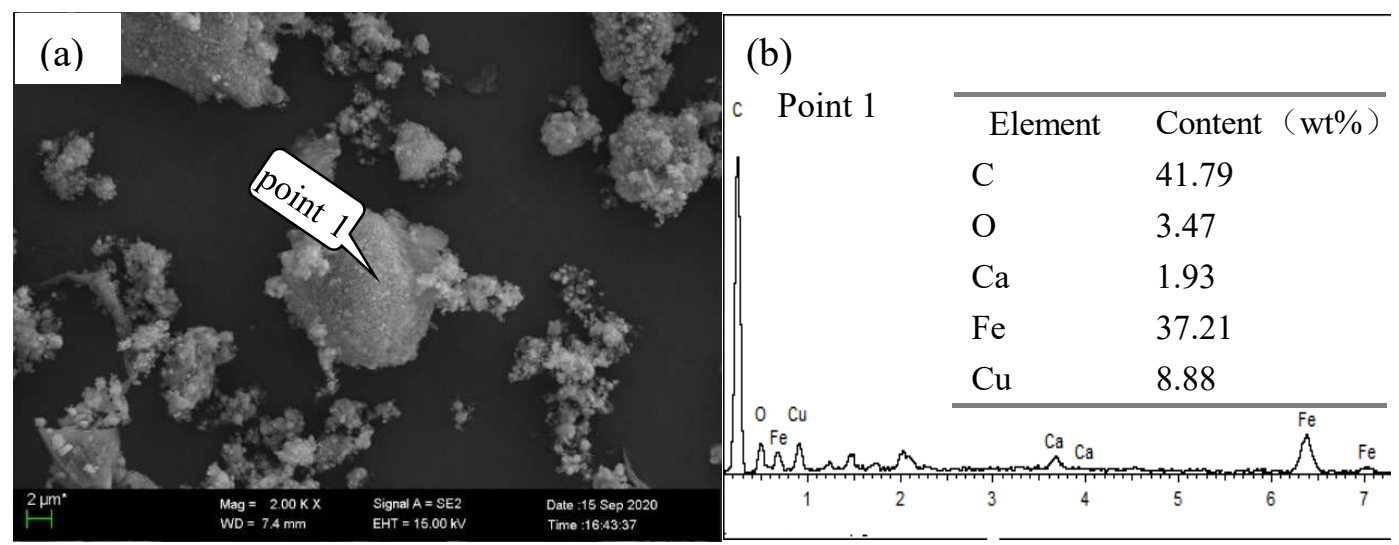

Figure 4. SEM image and EDS results of $\mathrm{Fe}^{0}-\mathrm{BC}-1200$

\section{Removal performance}

\section{Removal efficiency}

Figure 5 shows the removal efficiency of $\mathrm{RB}$ on $\mathrm{Fe}^{0}-\mathrm{BC}$ prepared at different temperatures. It is obvious to see that $\mathrm{Fe}^{0}-\mathrm{BC}-1200$ showed the best removal ability on $\mathrm{RB}$, with the removal efficiency reaching more than $99 \%$ after 30 min, followed by $\mathrm{Fe}^{0}$ BC-1100, with the removal efficiency of $86 \%$. However, the three other materials exhibited relatively low removal ability, with the removal efficiency was under $60 \%$. Compared with the XRD results in Figure 3, the presence of $\mathrm{Fe}^{0}$ was the main difference between these materials, demonstrating that the reduction of Fe played a key role in the removal process of $\mathrm{RB}$. In addition, the order of removal efficiency of the three materials without $\mathrm{Fe}^{0}$ was $\mathrm{Fe}^{0}-\mathrm{BC}-800>\mathrm{Fe}^{0}-\mathrm{BC}-900>\mathrm{Fe}^{0}-\mathrm{BC}-1000$, which was consistent to that of their specific surface areas (shown in Table 3). This result can be ascribed to the fact that smaller specific surface area implies the lower adsorption sites and worse absorption performance. 


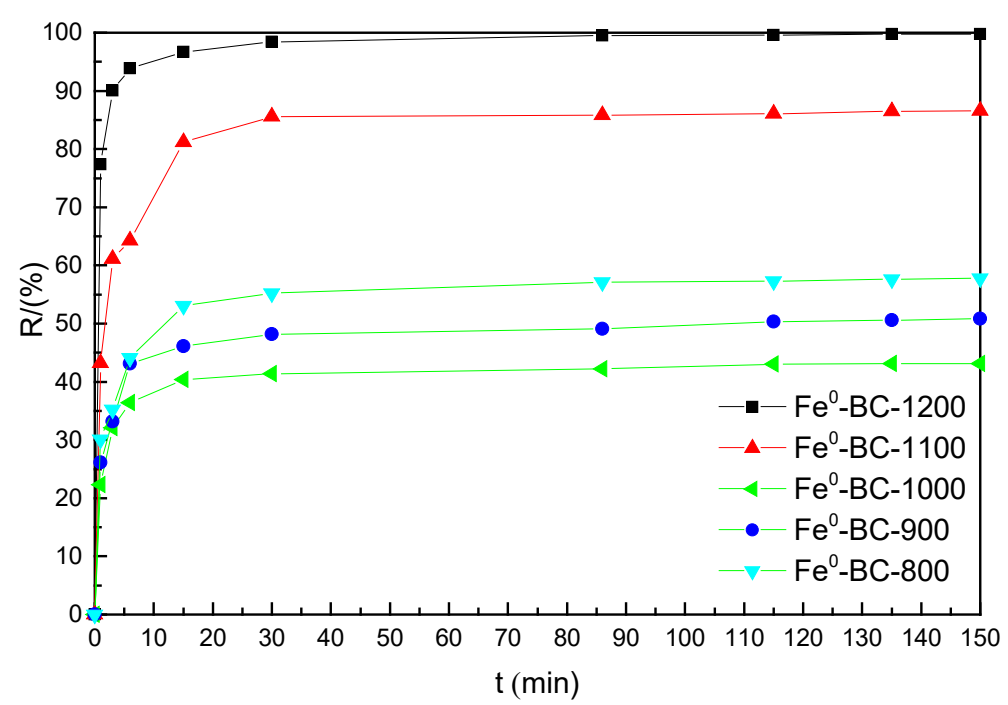

Figure 5. Removal efficiency on $\mathrm{RB}$ using various $\mathrm{Fe}^{0}-\mathrm{BC}$ materials $\left(C_{0}=100 \mathrm{mg} / \mathrm{L}, \mathrm{pH}=4.02\right.$, dosage $=2 \mathrm{~g} / \mathrm{L}, \mathrm{T}=25^{\circ} \mathrm{C}$ ).

For in-depth understanding of the effects of $\mathrm{Fe}^{0}$ and $\mathrm{BC}$ on the removal of $\mathrm{RB}$, the removal efficiency of $\mathrm{RB}$ on $\mathrm{BC}-\mathrm{T}$ and $\mathrm{Fe}^{0}$ powder was investigated. As shown in Figure 6 , it is clear that the removal efficiency decreased with the increase of temperature. In general, a high temperature can accelerate carbon graphitization, causing worse adsorption capacity (Yu et al., 2019). Besides, compared the results in Figure 5, the removal efficiency using BC-1000, BC-900 and BC-800 was higher than that of $\mathrm{Fe}^{0}-\mathrm{BC}-1000, \mathrm{Fe}^{0}-\mathrm{BC}-900$ and $\mathrm{Fe}^{0}-\mathrm{BC}-800$, respectively. This is because of $\mathrm{BC}-$ $\mathrm{T}$ contained more biochar at the same dosage, and other compositions in $\mathrm{Fe}^{0}-\mathrm{BC}-1000$, $\mathrm{Fe}^{0}-\mathrm{BC}-900$ and $\mathrm{Fe}^{0}-\mathrm{BC}-800$ had no positive effect on $\mathrm{RB}$ removal.Moreover, the ultimate removal efficiency of RB on BC-1200 was only $48 \%$, which was much lower than that of $\mathrm{Fe}^{0}-\mathrm{BC}-1200$, whereas the $\mathrm{Fe}^{0}$ powder had no removal ability on $\mathrm{RB}$, with the removal efficiency of $0 \%$. The result suggested that the favorable removal efficiency of $\mathrm{RB}$ on $\mathrm{Fe}^{0}-\mathrm{BC}-1200$ was attributed to the interaction of various multiple components. As a reducing active site, the presence of $\mathrm{Fe}^{0}$ on biochar surface could effectively degrade RB, and the removal efficiency improved simultaneously. 


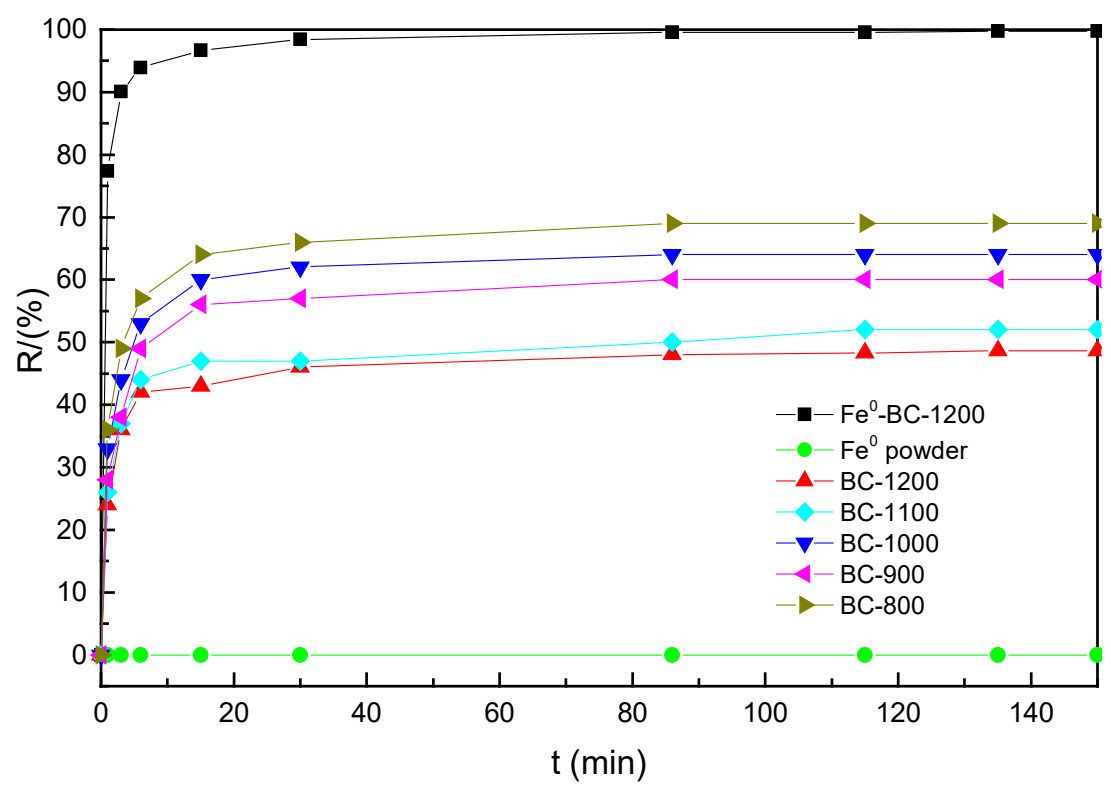

Figure 6. Removal efficiency on $\mathrm{RB}$ using $\mathrm{BC}$ and $\mathrm{Fe}^{0}$ powder $\left(C_{0}=100 \mathrm{mg} / \mathrm{L}, \mathrm{pH}=4.02\right.$, dosage $=2 \mathrm{~g} / \mathrm{L}, \mathrm{T}=25^{\circ} \mathrm{C}$ ).

From the above results, it can be indicated that the main factors affecting removal efficiency of $\mathrm{RB}$ on $\mathrm{Fe}^{0}-\mathrm{BC}$ were the amount of $\mathrm{Fe}^{0}$ particles and the specific surface area, while the $\mathrm{Fe}^{0}$ particles had dominant influence. Consequently, a high temperature 252 is necessary to obtain $\mathrm{Fe}^{0}$ - $\mathrm{BC}$ with better performance on $\mathrm{RB}$ removal due to more $\mathrm{Fe}^{0}$ 253 particles generated.

\section{Adsorption kinetic}

The removal capacities of $\mathrm{RB}$ on $\mathrm{Fe}^{0}-\mathrm{BC}-1200$ and the linear transformed models of the pseudo-first-order and pseudo-second-order models are presented in Figure 7. As shown in Figure 7(a), RB was removed rapidly in the first 10 min and tends to balance after $20 \mathrm{~min}$. The structure of $\mathrm{Fe}^{0}-\mathrm{BC}-1200$ with high specific surface area accelerated the mass transfer process, which is benefit to improve the removal rate of RB. Table 4

260 shows the fitting kinetics parameters in Figure 7(a) and Figure 7(b). Clearly, the 261 goodness of fit $\left(\mathrm{R}^{2}\right)$ of the pseudo-second-order model was 0.9998 , which is much 262 higher than that of the pseudo-first-order model of 0.8256 . Moreover, the $q_{e}$ calculated 263 by pseudo-second-order was $49.93 \mathrm{mg} / \mathrm{g}$, that was in good agreement with the 264 experimental data compared with the pseudo-first-order model of $7.46 \mathrm{mg} / \mathrm{g}$. Therefore, 265 the pseudo-second-order model fits well to the experiment data, indicated that the 266 removal process of $\mathrm{RB}$ by $\mathrm{Fe}^{0}$ - $\mathrm{BC}-1200$ resulted from the synergetic effect including 267 physical and chemical adsorption. 

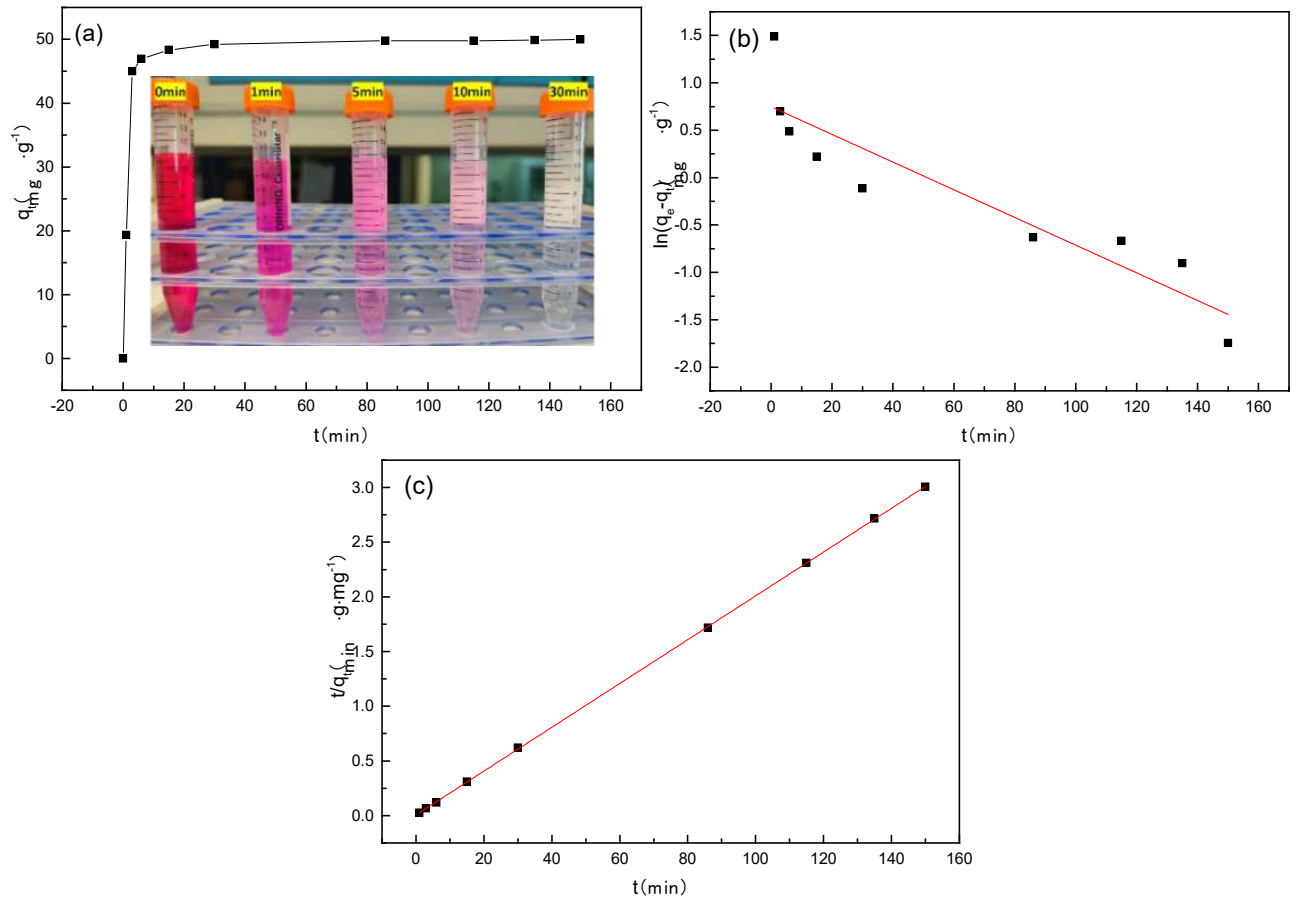

Figure 7. Removal capacities of $\mathrm{RB}$ on $\mathrm{Fe}^{0}-\mathrm{BC}-1200$ with time(a), kinetic liner plots of pseudofirst-order model (b) and pseudo-second-order model (c) $\left(C_{0}=100 \mathrm{mg} / \mathrm{L}, \mathrm{pH}=4.02\right.$, dosage $=2 \mathrm{~g} / \mathrm{L}$, $\left.\mathrm{T}=25^{\circ} \mathrm{C}\right)$.

Table 4 Kinetics parameters for sorption of RB on Fe-C-1200

\begin{tabular}{cccccc}
\hline \multicolumn{3}{c}{ Pseudo-first-order model } & \multicolumn{3}{c}{ Pseudo-second-order model } \\
\hline$q_{e}(\mathrm{mg} / \mathrm{g})$ & $k_{1}\left(\mathrm{~min}^{-1}\right)$ & $\mathrm{R}^{2}$ & $q_{e}(\mathrm{mg} / \mathrm{g})$ & $k_{2}(\mathrm{~g} /(\mathrm{mg} \cdot \mathrm{min}))$ & $\mathrm{R}^{2}$ \\
\hline 7.46 & 0.014 & 0.8256 & 49.93 & 0.0062 & 0.9998 \\
\hline
\end{tabular}

\section{Effect of pH on RB removal}

Usually, rhodamine B wastewater has acidic property. Thus, the effect of various initial $\mathrm{pH}$ values on $\mathrm{RB}$ removal by $\mathrm{Fe}^{0}-\mathrm{BC}-1200$ was investigated under acidic conditions, and the results are shown in Figure 8. Within 1 min, the removal efficiencies were $99 \%, 90 \%, 77 \%$, and $82 \%$ at initial $\mathrm{pH}$ values of $1.5,2.5,4.02$, and 6 , respectively. This trend showed that the removal rate significantly increased with the decrease of $\mathrm{pH}$. The reasons of this fact are presented as follows: On the one hand, $\mathrm{Fe}^{0}$ is more easily oxidized to $\mathrm{Fe}^{2+}$ under acidic conditions as presented in Eq. (7) (Peng et al., 2017; Li et al., 2017), and the reaction with RB was promoted at the same time; on the other hand, some polar groups were generated on the biochar surface during the adsorption process, and these polar groups displayed the ability of polarized adsorption under acidic conditions (Zhang et al., 2018; Qian et al., 2017).Thus, the adsorption capacity of biochar was enhanced. Moreover, above $99 \%$ removal efficiency was obtained within 30 min at all tested initial $\mathrm{pH}$ values. It revealed that the prepared $\mathrm{Fe}^{0}-\mathrm{BC}-1200$ could exhibit outstanding removal capacity in practical situation.

$$
\mathrm{Fe}^{0}+\mathrm{H}_{2} \mathrm{O} \longrightarrow \mathrm{Fe}^{2+}+\mathrm{H}_{2}+2 \mathrm{OH}^{-}
$$




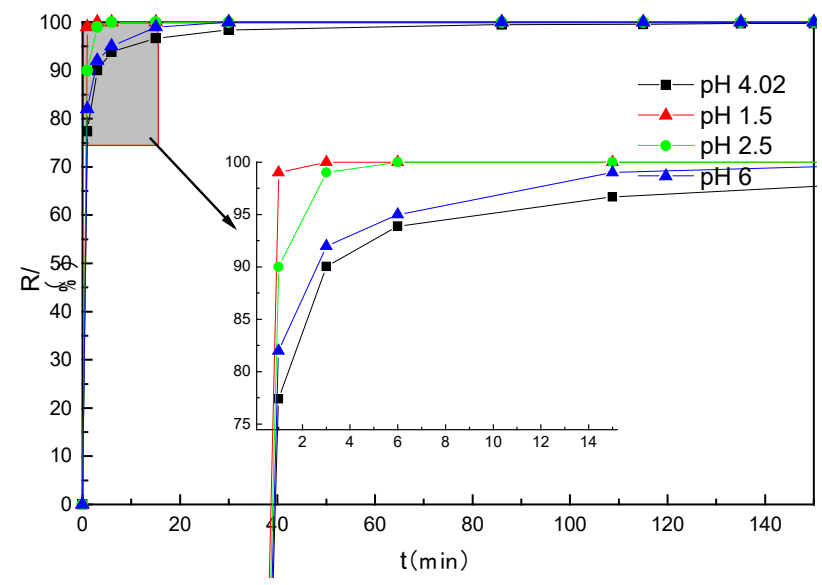

Figure 8. Effects of initial solution $\mathrm{pH}$ on removal efficiency by Fe ${ }^{0}-\mathrm{BC}-1200\left(C_{0}=100 \mathrm{mg} / \mathrm{L}\right.$, dosage $=2 \mathrm{~g} / \mathrm{L}, \mathrm{T}=25^{\circ} \mathrm{C}$ ).

In order to futher investigate the effect of $\mathrm{pH}$ on the removal of $\mathrm{RB}$, the solution $\mathrm{pH}$ values were determined at different selected reaction time, and the results are shown in Figure 9. From the picture, the curves of $\mathrm{pH}$ value with time presented the same trend as follows: a rapid increase at first, followed by decrease, and then a slow increase again, and eventually stabilized at about 9 . This finding could be explained as follows. The reaction between $\mathrm{Fe}^{0}$ and $\mathrm{H}_{2} \mathrm{O}$ (Eq. (7)) was conducted rapidly when $\mathrm{Fe}^{0}-\mathrm{BC}-1200$ was added to the RB solution. Slight oxidation occurred on the surface and a large amount of $\mathrm{H}_{2}$ was produced in a short time. Therefore, the $\mathrm{pH}$ value increased rapidly at first. Then, due to the severe oxidation or corrosion on the surface of $\mathrm{Fe}^{0}$ and the accumulation of $\mathrm{Fe}^{2+}$ and $\mathrm{H}_{2}$, the reaction rate of Eq. (7) was less than that of Eq. (8), so $\mathrm{Fe}^{2+}$ was reduced and $\mathrm{pH}$ value decreased at the same time. At last, the $\mathrm{pH}$ value increased again, which may be ascribed to the formation of a coupling pair between $\mathrm{Fe}^{0}$ and $\mathrm{Cu}^{0}$. Because of the high standard electrode potentials difference betwwen $\mathrm{Fe}^{0}$ ($0.44 \mathrm{~V})$ and $\mathrm{Cu}^{0}(0.34 \mathrm{~V})$ (Bratsch and Steven, 1989), the electrical current flowed from relatively active $\mathrm{Fe}^{0}$ to $\mathrm{Cu}^{0}$ and the active atom hydrogen $\left(\mathrm{H}^{*}\right)$ was simultaneously generated with $\mathrm{H}^{+}$adsorbed on the copper surface (Eq. (9)) (Wang et al., 2017) and the presence of $\mathrm{H}^{*}$ reinforced the reduced process of RB (Xiong et al., 2016). Due to the consumption of $\mathrm{H}^{+}$, the $\mathrm{pH}$ value increased again, and finally reached the equilibrium state. As one of the most important physical and chemical parameters in this reaction system, the change of $\mathrm{pH}$ value demonstrated that $\mathrm{Cu}^{0}$ may play a catalytic role in $\mathrm{RB}$ removal by $\mathrm{Fe}^{0}-\mathrm{BC}-1200$.

$$
\begin{aligned}
& \mathrm{Fe}^{2+}+2 \mathrm{e}^{-} \longrightarrow \mathrm{Fe}^{0} \\
& \mathrm{FeCu}+\mathrm{H}^{+}+\mathrm{e}^{-} \longrightarrow \mathrm{FeCuH}^{*}
\end{aligned}
$$




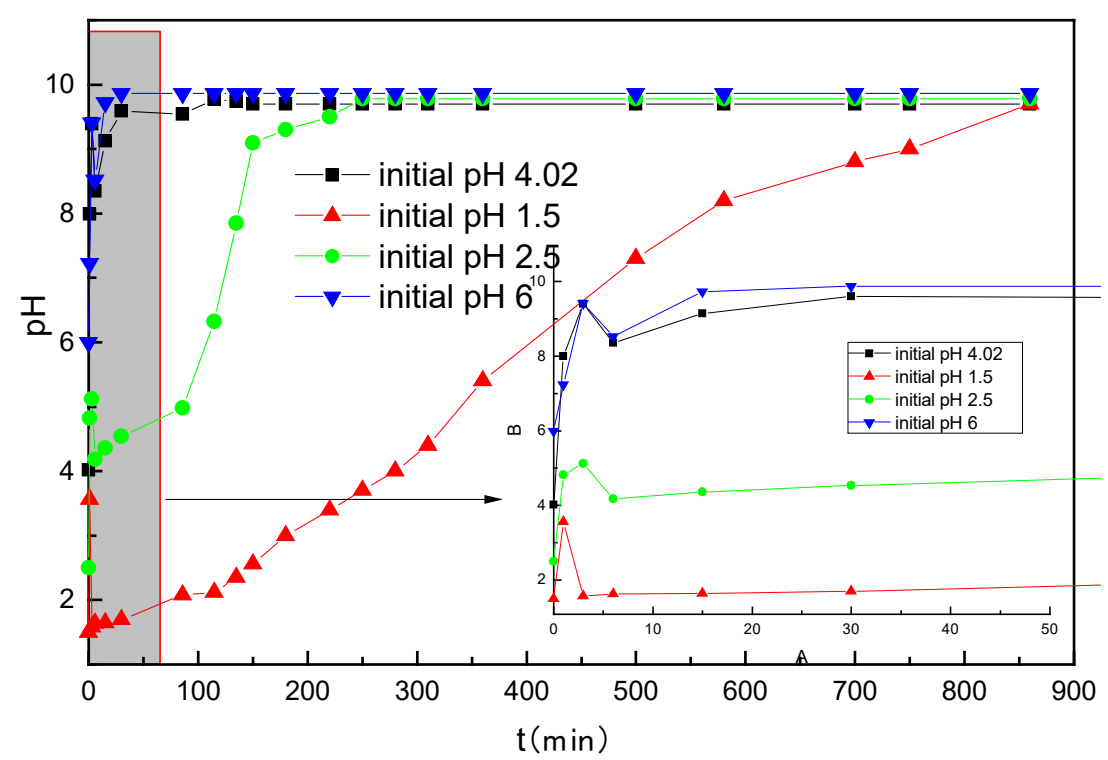

Figure 9. Solution $\mathrm{pH}$ at different selected sample time $\left(C_{0}=100 \mathrm{mg} / \mathrm{L}\right.$, dosage $=2 \mathrm{~g} / \mathrm{L}$, $\left.\mathrm{T}=25^{\circ} \mathrm{C}\right)$.

\section{Mechanisms analysis}

317 The residual products at different reaction time during the process of RB removal by $318 \mathrm{Fe}^{0}-\mathrm{BC}-1200$ were detected by LCMC, and the results are shown in Figure 10. Figure 319 10(a) presents the mass spectra of RB solution without adding $\mathrm{Fe}^{0}-\mathrm{BC}-1200, \mathrm{~m} / \mathrm{z} 443$ 320 and 444 were molecular ion peaks of RB ions or its isotopes. The molecular iron peaks 321 of RB were strong and its molecular fragment peaks were small and weak. Thus, the RB molecular structure was possibly not destroyed under ESI MS. As shown in Figure 10(b), the result of MS at 1 min was basically consistent with that of Figure 10(a), indicating that RB was not degraded in the first $1 \mathrm{~min}$. However, compared with the result in Figure 5, the concentration of RB decreased by 77\% within $1 \mathrm{~min}$, this finding proved that the $1 \mathrm{RB}$ removal is mainly reached by physical adsorption in the early stage. As shown in Figure 10(c), new molecular ion peaks were observed in the MS result at 15 min, among which $\mathrm{m} / \mathrm{z} 331$ was the molecular ion peak of RB with four ethyl groups removed (Horikoshi et al., 2002), and $\mathrm{m} / \mathrm{z}$ 107, 143 and 201 were the molecular iron peaks of small molecule products after the benzene rings in RB were opened (Jun et al., 2020). The molecular ion peak of RB disappeared and the molecular iron peak of small molecules strengthened in the result of mass spectrometry at 30min, as shown in Figure 10(d), indicating that RB was completely degraded. The above results confirm that RB was degraded in the removal process.

To further understand the mechanisms of $\mathrm{Fe}^{0}-\mathrm{BC}-1200$ for $\mathrm{RB}$ removal, the XRD of $\mathrm{Fe}^{0}-\mathrm{BC}-1200$ before and after $\mathrm{RB}$ removal were analyzed, and the results were shown in Figure 11. After reacting with the RB solution, the diffraction peaks of $\mathrm{Fe}^{0}$ located at $44.2^{\circ}, 65.0^{\circ}$ and $82.3^{\circ}$ weakened and the diffraction peaks of $\mathrm{Fe}_{2} \mathrm{O}_{3}$ and $\mathrm{Fe}_{3} \mathrm{O}_{4}$ located at $64.1^{\circ}$ and $35.4^{\circ}$ were detected, illustrating that the redox reaction occurred 
between $\mathrm{Fe}^{0}$ and $\mathrm{RB}$ and $\mathrm{Fe}^{0}$ was oxidized to $\mathrm{Fe}^{2+}$ and $\mathrm{Fe}^{3+}$. Therefore, $\mathrm{Fe}^{0}-\mathrm{BC}-1200$ is considered an efficient reductant to remove $\mathrm{RB}$. In addition, the phase of $\mathrm{Cu}$ showed no difference, indicating that $\mathrm{Cu}^{0}$ only play a catalytic role and did not participate

343 directly in the degradation of RB.
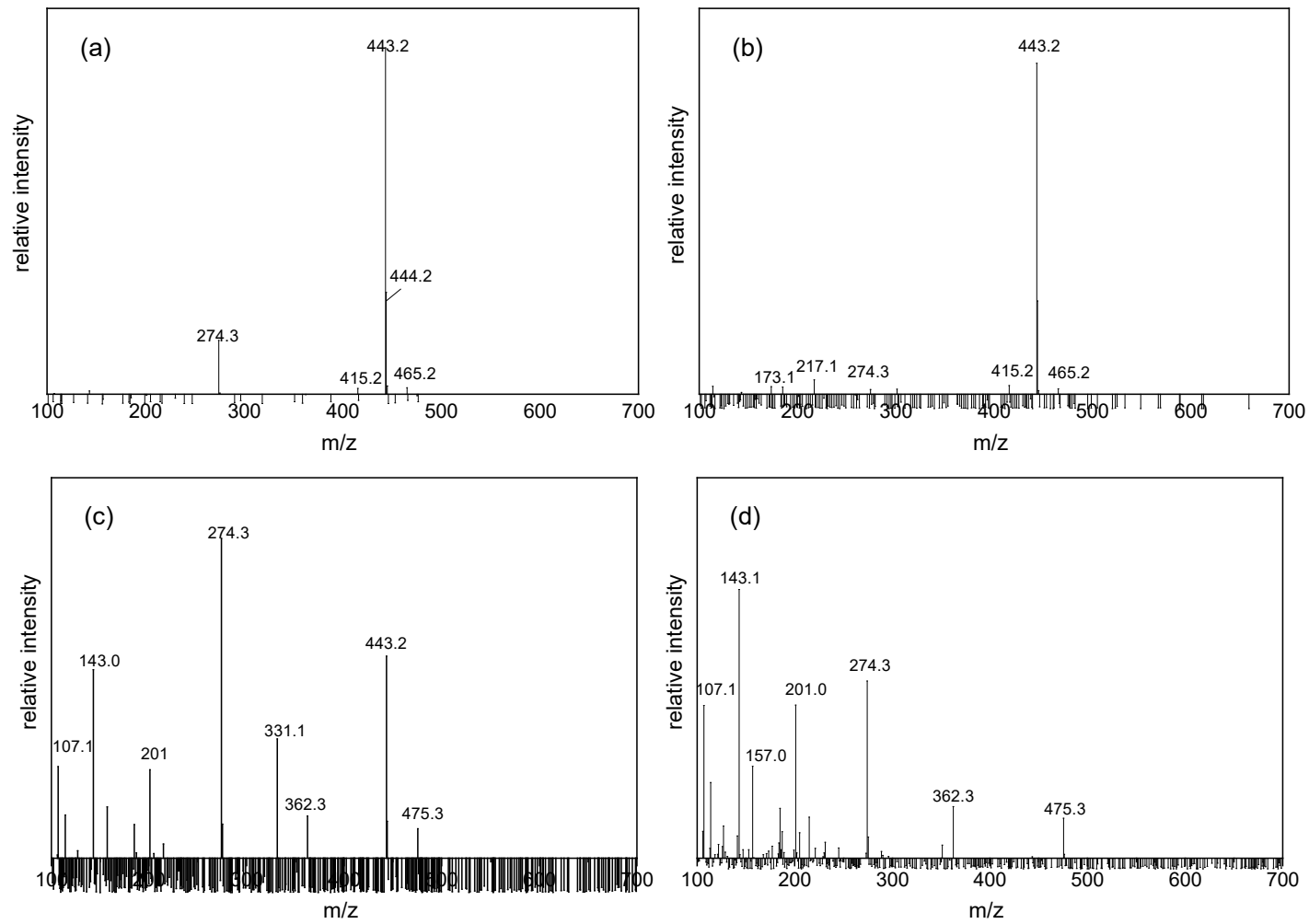

Figure 10. Mass spectra of RB at different reaction time: (a) 0min, (b) $1 \mathrm{~min}$, (c) $15 \mathrm{~min}$, (d) $30 \mathrm{~min}$.

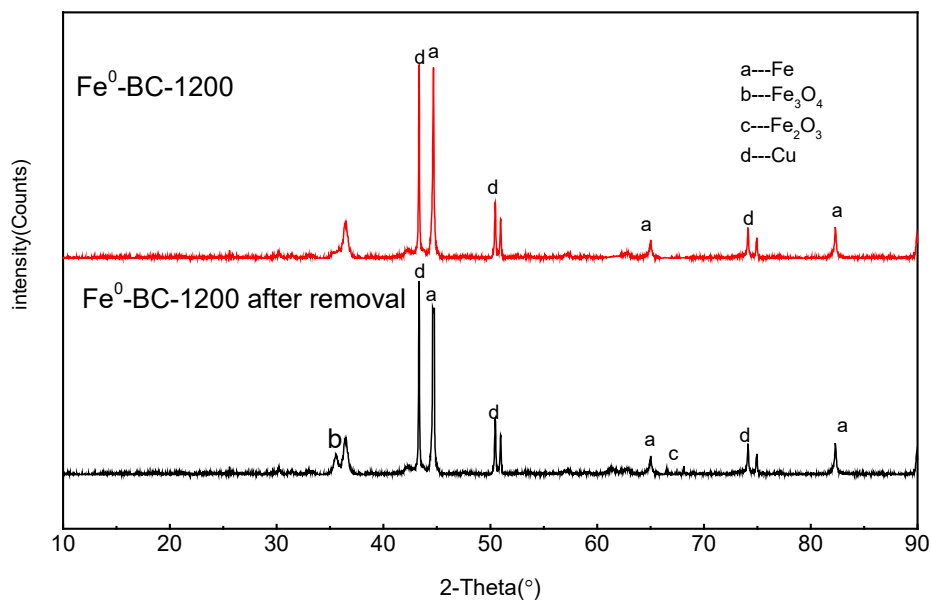

Figure 11. XRD patterns of $\mathrm{Fe}^{0}$-BC-1200 before and after removal of $\mathrm{RB}$

Based on the above results, it can be concluded that the removal mechanism of $\mathrm{Rb}$ by $\mathrm{Fe}^{0}$-BC-1200 mainly includes the following: 1) In the initial stage of reaction, $\mathrm{RB}$ 351 was adsorbed on the surface of biochar mainly through physical adsorption; 2) 352 Subsequently, abundant microscopic primary cells formed between the $\mathrm{Fe}^{0}$ particles 353 located on the biochar surface and biochar itself. The presence of $\mathrm{Cu}$ catalyzed this 354 process, and the electrons flowed to $\mathrm{Cu}^{0}$ with low potential, thereby promoting the corrosion of $\mathrm{Fe}^{0}$, accelerating the electron transfer with $\mathrm{RB}$. This redox action destroyed 
the $\mathrm{C}-\mathrm{N}$ bond of the RB molecular branched chain and removed ethyl. Then the deethylated products underwent ring-opening reaction and generated many organic compounds with small mass charge ratio, followed by complete degradation. The mechanism diagram of $\mathrm{RB}$ removal by $\mathrm{Fe}^{0}-\mathrm{BC}-1200$ is presented in Figure 12.

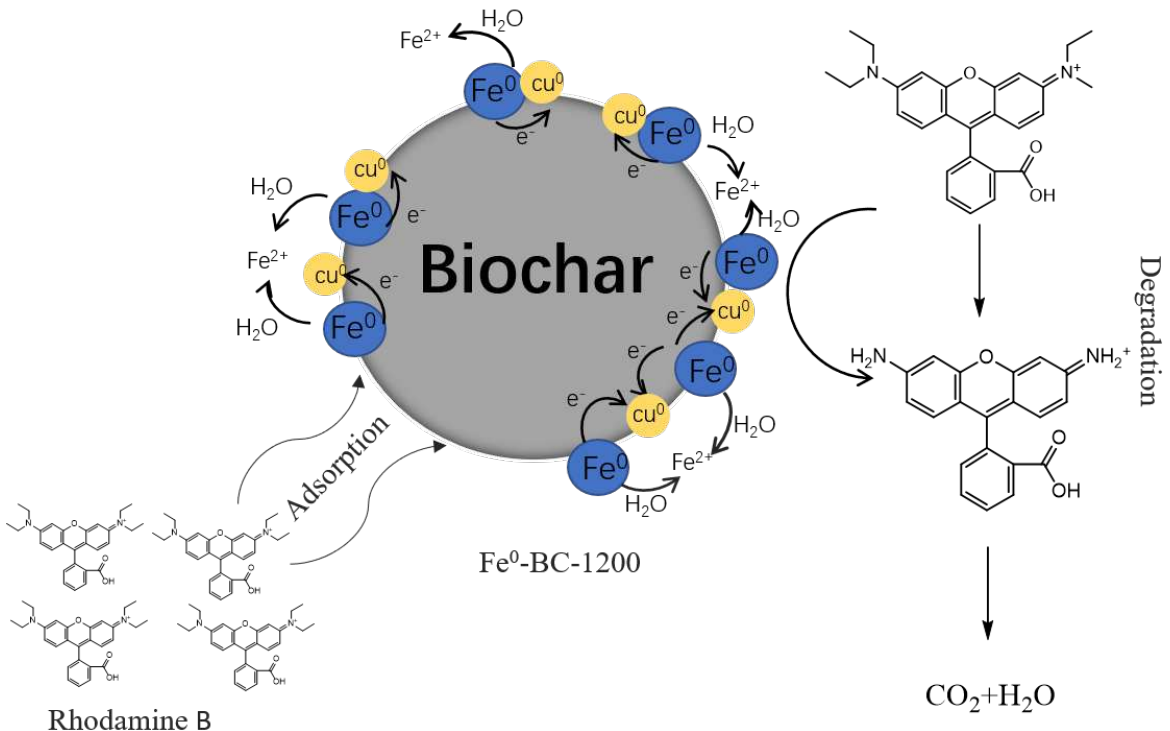

Figure 12. Mechanism diagram of RB removal by $\mathrm{Fe}^{0}-\mathrm{BC}-1200$.

\section{Conclusions}

364 In this study, wood waste and iron sludge were used as carbon and iron sources, respectively, and a new process was proposed to synthesize the zero-valent iron/biochar $\left(\mathrm{Fe}^{0}-\mathrm{BC}\right)$ by carbothermal reduction under the condition of oxygen isolation. Characterization results showed that $\mathrm{Fe}^{0}-\mathrm{BC}-1200$ prepared at $1200{ }^{\circ} \mathrm{C}$ has the advantages of large specific surface area, small granularity of $\mathrm{Fe}^{0}$ particles and high $\mathrm{Fe}^{0}$ loading on the biochar surface. Besides, $\mathrm{Fe}^{0}-\mathrm{BC}-1200$ showed excellent performance on removal of $\mathrm{RB}$, and the equilibrium adsorption capacity reached $49.93 \mathrm{mg} / \mathrm{g}$ when the initial concentration of $\mathrm{RB}$ and the dosage of $\mathrm{Fe}^{0}-\mathrm{BC}-1200$ were $100 \mathrm{mg} / \mathrm{L}$ and $2 \mathrm{~g} / \mathrm{L}$, respectively. The pseudo-second-order model was suitable to fit the removal experimental data. Meanwhile, the removal mechanism included the physical adsorption of biochar and the redox reaction of $\mathrm{Fe}^{0}$. The presence of $\mathrm{Cu}^{0}$ was conducive to catalyze the oxidation of iron, thus enhancing the degradation effect. Therefore, the carbon supported by the zero-valent iron material prepared by carbothermal reduction process with low cost of raw materials, no additional reductant, simple operation, and significant detoxification effect, has the potential of industrial production. 
Ethics approval and consent to participate Not applicable Availability of data and materials The datasets used and analysed during the current study are available from the corresponding author on reasonable request. Competing Interests The authors declare that they have no conflict of interest. Authors Contributions Jianguo Liu contributed to the conception of the study; Chao Chen, Chao Gen and Wenzhi Qi performed the experiment; Chao Chen performed the data analyses and wrote the manuscript; Qin Liu, Xuetao Zhu and Fang Wang helped perform the analysis with constructive discussions. All authors commented on previous versions of the manuscript and approved the final manuscript.

Acknowledgements and funding information The authors are grateful for the support of National Key R\&D Program of China (Grant No. 2108YFC1902906), the natural science foundation of China (No. 51674018), and the Postdoctoral Sustentation Fund, China (Grant No. 2018M631488).

\section{References}

Bakshi, S., Banik, C., Rathke, S. J., Laird, D. A., 2018. Arsenic sorption on zero-valent iron-biochar complexes. Water research, 137, 153-163.

Bratsch, S. G., 1989. Standard electrode potentials and temperature coefficients in water at 298.15 K. Journal of Physical and Chemical Reference Data, 18(1), 1-21.

Barzegar, G., Jorfi, S., Zarezade, V., Khatebasreh, M., Mehdipour, F., Ghanbari, F., 2018. 4-Chlorophenol degradation using ultrasound/peroxymonosulfate/nanoscale zero valent iron: reusability, identification of degradation intermediates and potential application for real wastewater. Chemosphere 201, 370-379.

Calderon B., Fullana A., 2015. Heavy metal release due to aging effect during zero valent iron nanoparticles remediation. Water research, 83, 1-9.

Chen, C., Sun, T., Wang, X., Hu, T., 2017. Effects of MgO on the reduction of vanadium titanomagnetite concentrates with char. JOM, 69(10), 1759-1766.

Chen, C., Sun, T., Geng, C., Kou, J., Liu, J., 2019. Formation and Mechanism of Magnesium Titanate in the Process of Ilmenite Reduction. Mineral Processing and Extractive Metallurgy Review, 1-10.

Chen, X., Chen, G., Chen, L., Chen, Y., Lehmann, J., McBride, M.B., Hay, A.G., 2011.Adsorption of copper and zinc by biochars produced from pyrolysis of hardwood andcorn straw in aqueous solution. Bioresource technology, 102(19), 8877-8884.

Demirbaş, A., 2005. Estimating of structural composition of wood and non-wood biomass samples. Energy Sources, 27(8), 761-767.

Devi, P., Saroha, A. K., 2014. Synthesis of the magnetic biochar composites for use as an adsorbent for the removal of pentachlorophenol from the effluent. Bioresource 
Technology, 169, 525-531.

418 Dewage, N. B., Liyanage, A. S., Pittman Jr, C. U., Mohan, D., Mlsna, T., 2018. Fast 419 nitrate and fluoride adsorption and magnetic separation from water on $\alpha-\mathrm{Fe}_{2} \mathrm{O}_{3}$ and $420 \quad \mathrm{Fe}_{3} \mathrm{O}_{4}$ dispersed on Douglas fir biochar. Bioresource technology, 263, 258-265.

421 Dong, H., Zhang, C., Hou, K., Cheng, Y., Deng, J., Jiang, Z., Tang., Zeng, G., 2017.

422 Removal of trichloroethylene by biochar supported nanoscale zero-valent iron in aqueous solution. Separation and Purification Technology, 188, 188-196.

Dong, W., Lee, C. W., Lu, X., Sun, Y., Hua, W., Zhuang, G., Zhao, D., 2010. Synchronous role of coupled adsorption and photocatalytic oxidation on ordered mesoporous anatase $\mathrm{TiO}_{2}-\mathrm{SiO}_{2}$ nanocomposites generating excellent degradation activity of RhB dye. Applied Catalysis B: Environmental, 95 (3-4), 197-207.

Du, Q., Zhang, S., Song, J., Zhao, Y., Yang, F., 2020. Activation of porous magnetized biochar by artificial humic acid for effective removal of lead ions. Journal of Hazardous Materials, 389, 122115. Emandi, A., Vasiliu, C. I., Budrugeac, P., Stamatin, I., 2011. Quantitative investigation of wood composition by integrated ft-ir and thermogravimetric methods. Cellulose Chemistry and Technology, 45(9), 579-584.

Frick, H., Tardif, S., Kandeler, E., Holm, P., Brandt, K., 2018. Assessment of biochar and zero-valent iron for in-situ remediation of chromated copper arsenate contaminated soil. Science of the Total Environment, 655, 414-422.

Geng, C., Chen, C., Shi, X., Wu, S., Jia, Y., Du, B., Liu, J. 2020. Recovery of metals from municipal solid waste incineration fly ash and red mud via a co-reduction process. Resources, Conservation and Recycling, 154, 104600. utilization of MSWI fly ash through co-reduction with red mud to prepare crude alloy and cleaned slag. Journal of hazardous materials, 384, 121315.

Ghariani, B., Messaoud, M., Louati, I., Mtibaà, R., Nasri, M., Mechichi, T., 2019. Removal of Acid Orange 51 by micro zero-valent iron under different operational conditions and evaluation of toxicity. Environmental Science and Pollution Research, 26(18), 18392-18402. valent iron composite: effects on Cd immobilization and enzyme activities in Ulansuhai River sediments of China. Journal of Soils and Sediments, 19(5), 2650-2662. Hoch, L.B., Mack, E.J., Hydutsky, B.W., Hershman, J.M., Skluzacek, J.M., Mallouk, T.E., 2008. Carbothermal synthesis of carbon-supported nanoscale zero-valent iron particles for the remediation of hexavalent chromium. Environmental science \& technology, 42(7), 2600-2605. integrated microwave/UV-illumination method. 1. Microwave-assisted degradation of rhodamine-B dye in aqueous $\mathrm{TiO}_{2}$ dispersions. Environmental science \& technology,

458 Huang, H., Yao, W., Li, R., Ali, A., Du, J., Guo, D., Xiao, R., Guo, Z., Zhang, Z., 
Awasthi, M. K., 2018. Effect of pyrolysis temperature on chemical form, behavior and environmental risk of $\mathrm{Zn}, \mathrm{Pb}$ and $\mathrm{Cd}$ in biochar produced from phytoremediation residue. Bioresource technology, 249, 487-493.

Huang, H., Zhang, J., Jiang, L., Zang, Z., 2017. Preparation of cubic $\mathrm{Cu}_{2} \mathrm{O}$ nanoparticles wrapped by reduced graphene oxide for the efficient removal of rhodamine B. Journal of Alloys and Compounds, 718, 112-115.

Hussain, I., Li, M., Zhang, Y., Li, Y., Huang, S., Du, X., Liu, G., Hayat, W., Anwar, N., 2017. Insights into the mechanism of persulfate activation with nZVI/BC nanocomposite for the degradation of nonylphenol. Chemical Engineering Journal, 311, 163-172.

Jun, B. M., Elanchezhiyan, S. S., Yoon, Y., Wang, D., Kim, S., Prabhu, S. M., Park, C. M., 2020. Accelerated photocatalytic degradation of rhodamine B over carbonate-rich lanthanum-substituted zinc spinel ferrite assembled reduced graphene oxide by ultraviolet (UV)-activated persulfate. Chemical Engineering Journal, 124733.

Kong, L., Zhang, H., Shih, K., Su, M., Diao, Z., Long, J., Chen, D., 2018. Synthesis of FC-supported Fe through a carbothermal process for immobilizing uranium. Journal of hazardous materials, 357, 168-174.

Lawrinenko, M., Wang, Z., Horton, R., Mendivelso-Perez, D., Smith, E. A., Webster, T. E., van Leeuwen, J. H., 2017. Macroporous carbon supported zerovalent iron for remediation of trichloroethylene. ACS Sustainable Chemistry \& Engineering, 5(2), 1586-1593.

Li, H., Zhu, F., He, S., 2019. The degradation of decabromodiphenyl ether in the ewaste site by biochar supported nanoscale zero-valent iron/persulfate. Ecotoxicology and environmental safety, 183, 109540.

Li, X., Zhao, Y., Xi, B., Meng, X., Gong, B., Li, R., Liu, H., 2017. Decolorization of methyl orange by a new clay-supported nanoscale zero-valent iron: synergetic effect, efficiency optimization and mechanism. Journal of Environmental Sciences, 52, 8-17. Li, Z., Sun, Y., Yang, Y., Han, Y., Wang, T., Chen, J., Tsang, D. C., 2020. Biocharsupported nanoscale zero-valent iron as an efficient catalyst for organic degradation in groundwater. Journal of hazardous materials, 383, 121240.

Liu, F., Zuo, J., Chi, T., Wang, P., Yang, B., 2015. Removing phosphorus from aqueous solutions by using iron-modified corn straw biochar. Frontiers of Environmental Science \& Engineering, 9(6), 1066-1075.

Liu, H., Chen, T., Xie, Q., Zou, X., Chen, C., Frost, R. L., 2015. The functionalization of limonite to prepare NZVI and its application in decomposition of p-nitrophenol. Journal of Nanoparticle Research, 17(9), 374.

Liu, J., Yu, Y., Zhu, S., Yang, J., Song, J., Fan, W., Yu, H., Bian, D., Huo, M., 2018. Synthesis and characterization of a magnetic adsorbent from negatively-valued iron mud for methylene blue adsorption. PloS one, 13(2), e0191229.

Liu, W., Chen, X., Li, W., Yu, Y., Yan, K., 2014. Environmental assessment, management and utilization of red mud in China. Journal of Cleaner Production, 84, 606-610. 
501 Lops, C., Ancona, A., Di Cesare, K., Dumontel, B., Garino, N., Canavese, G., 502 Hérnandez, S., Cauda, V., 2019. Sonophotocatalytic degradation mechanisms of 503 Rhodamine B dye via radicals generation by micro-and nano-particles of $\mathrm{ZnO}$. Applied 504 Catalysis B: Environmental, 243, 629-640.

505 Mandal, S., Sarkar, B., Bolan, N., Ok, Y. S., Naidu, R., 2017. Enhancement of chromate 506 reduction in soils by surface modified biochar. Journal of environmental management, 507 186, 277-284.

508 Mitzia, A., Vítková, M., Komárek, M., 2020. Assessment of biochar and/or nano zero509 valent iron for the stabilisation of $\mathrm{Zn}, \mathrm{Pb}$ and $\mathrm{Cd}$ : A temporal study of solid phase Geochemistry under changing soil conditions. Chemosphere, 242, 125248.

511 Oh, S.Y., Seo, Y.D., Ryu, K.S., 2016. Reductive removal of 2, 4-dinitrotoluene and 2, 512 4-dichlorophenol with zero-valent iron-included biochar. Bioresource technology, 2016, 513 216, 1014-1021.

514 Oleszczuk, P., Kołtowski, M., 2017. Effect of co-application of nano-zero valent iron 515 and biochar on the total and freely dissolved polycyclic aromatic hydrocarbons removal 516 and toxicity of contaminated soils. Chemosphere, 2017, 168, 1467-1476.

517 Pani, B., Chandrasekhar, P., Singh, S., 2019. Investigation of erosion behaviour of an 518 iron-mud filled glass-fibre epoxy hybrid composite. Bulletin of Materials Science, 519 42(5), 217.

520 Peng, A., Huang, M., Chen, Z., Gu, C., 2017. Oxidative coupling of acetaminophen 521 mediated by $\mathrm{Fe}^{3+}$-saturated montmorillonite. Science of The Total Environment, 595, 522 673-680.

523 Pourrezaei, P., Alpatova, A., Khosravi, K., Drzewicz, P., Chen, Y., Chelme-Ayala, P., 524 ElDin, M.G., 2014. Removal of organic compounds and trace metals from oil sands 525 process-affected water using zero valent iron enhanced by petroleum coke. Journal of environmental management. 139, 50-58.

527 Qian, J., Shen, M., Wang, P., Wang, C., Li, K., Liu, J., Lu, B., Tian, X., 2017. 528 Perfluorooctane sulfonate adsorption on powder activated carbon: effect of phosphate

530 Qin, Y., Long, M., Tan, B., Zhou, B., 2014. RhB adsorption performance of magnetic 531 adsorbent $\mathrm{Fe} 3 \mathrm{O} 4 / \mathrm{rGO}$ composite and its regeneration through a Fenton-like reaction. 532 Nano-Micro Letters, 6(2), 125-135.

533 Reddy, A.V.B., Yusop, Z., Jaafar, J., Reddy, Y.V.M., Bin Aris, A., Majid, Z.A., Talib, J., 534 Madhavi, G., 2016. Recent progress on Fe-based nanoparticles: synthesis, properties, 535 characterization and environmental applications. Journal of environmental chemical 536 engineering, 4(3), 3537-3553.

537 Shang, J., Zong, M., Yu, Y., Kong, X., Du, Q., Liao, Q., 2017. Removal of chromium 538 (VI) from water using nanoscale zerovalent iron particles supported on herb-residue 539 biochar. Journal of environmental management, 197, 331-337.

540 Shen, Y., LI, T., Zhang, W., Gao, S., Cui, B., Wei, D., $\mathrm{NO}_{2}$ Sensing properties of $\alpha-$ 541 Fe2O3 nanoparticles synthesized from pyrite. The Journal of the University of Guizhou 542 (Natural Science), 2019,36(2):1-6. 
Sun, Y., Iris, K. M., Tsang, D. C., Cao, X., Lin, D., Wang, L., Feng, Y., 2019. Multifunctional iron-biochar composites for the removal of potentially toxic elements, inherent cations, and hetero-chloride from hydraulic fracturing wastewater. Environment international, 124, 521-532.

Tsoumis, G., 2013. Wood as raw material: source, structure, chemical composition, growth, degradation and identification. Elsevier.

Xiong, Z., Lai, B., Yuan, Y., Cao, J., Yang, P., Zhou, Y., 2016. Degradation of pnitrophenol (PNP) in aqueous solution by a micro-size $\mathrm{Fe}^{0} / \mathrm{O} 3$ process $\left(\mathrm{mFe}^{0} / \mathrm{O} 3\right)$ : Optimization, kinetic, performance and mechanism. Chemical Engineering Journal, 302, 137-145.

Wang, L., Yu, K., Li, J. S., Tsang, D. C., Poon, C. S., Yoo, J. C., Baek, K., Ding, S., Hou, D., Dai, J. G., 2018. Low-carbon and low-alkalinity stabilization/solidification of high-Pb contaminated soil. Chemical Engineering Journal, 351, 418-427.

Wang, T., Qin, Y., Cao, Y., Han, B., Ren, J., 2017. Simultaneous addition of zero-valent iron and activated carbon on enhanced mesophilic anaerobic digestion of wasteactivated sludge. Environmental Science and Pollution Research, 24(28), 22371-22381. Yu, W., Sun, Y., Lei, M., Chen, S., Qiu, T., Tang, Q., 2019. Preparation of microelectrolysis material from flotation waste of copper slag and its application for degradation of organic contaminants in water. Journal of hazardous materials, 361, 221227.

Zhang, K., Sun, P., Zhang, Y., 2019. Decontamination of Cr (VI) facilitated formation of persistent free radicals on rice husk derived biochar. Frontiers of Environmental Science \& Engineering, 13(2), 22.

Zhang, Y., Zuo, S., Zhou, M., Liang, L., Ren, G., 2018. Removal of tetracycline by coupling of flow-through electro-Fenton and in-situ regenerative active carbon felt adsorption. Chemical Engineering Journal, 335, 685-692.

Zhao, L., Zhao, Y., Nan, H., Yang, F., Qiu, H., Xu, X., Cao, X., 2020. Suppressed formation of polycyclic aromatic hydrocarbons (PAHs) during pyrolytic production of Fe-enriched composite biochar. Journal of hazardous materials, 382, 121033. Zhu, S., Dong, G., Yu, Y., Yang, J., Yang, W., Fan, W., Zhou, D., Liu, J., Zhang, L., Huo, M., Wang, Y., 2018. Hydrothermal synthesis of a magnetic adsorbent from wasted iron mud for effective removal of heavy metals from smelting wastewater. Environmental Science and Pollution Research, 25(23), 22710-22724. 
Figures

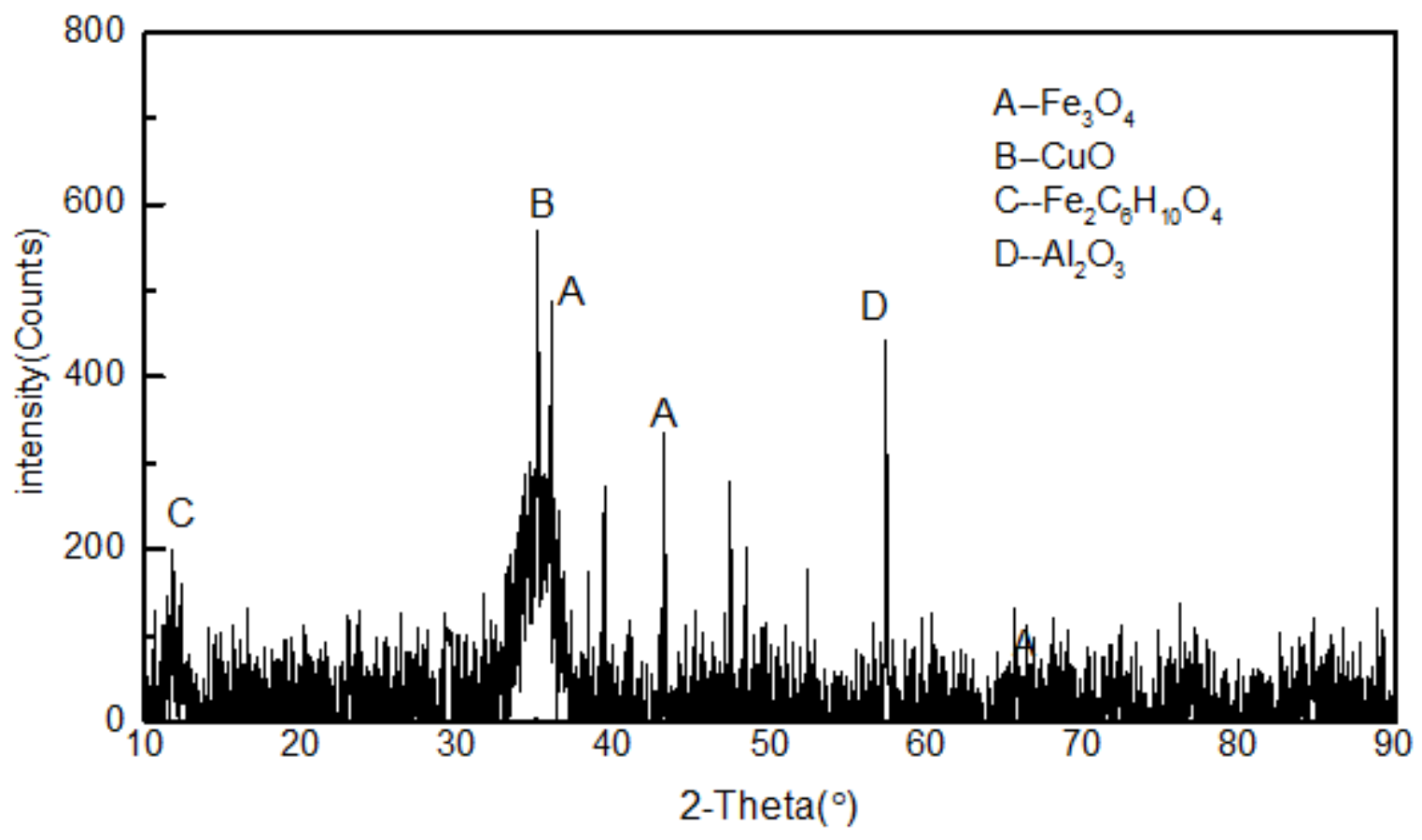

Figure 1

XRD patterns of the iron mud
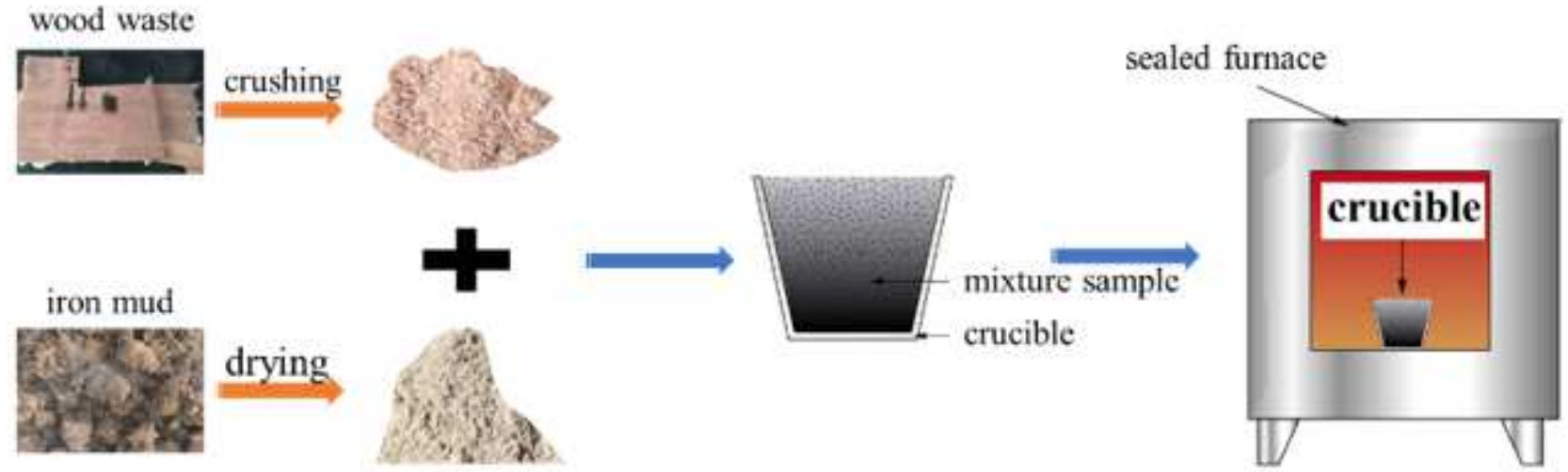

sealed furnace

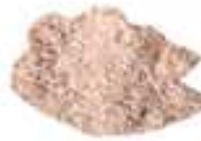

Mixing

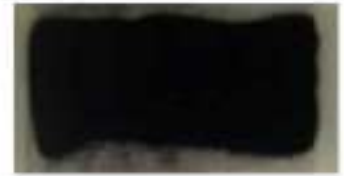

zero-valent iron/biochar

Characterization

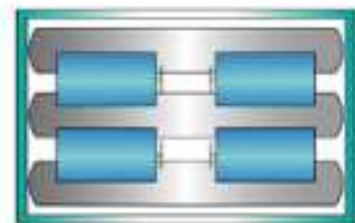

rod mill

Grinding
Reduction

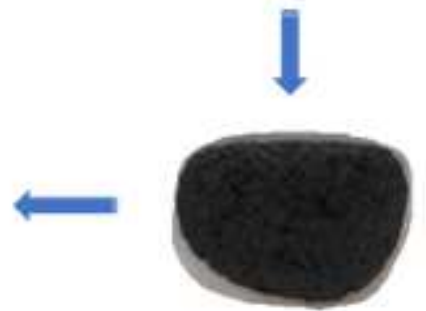

reduced sample

Cooling

Figure 2 
The preparation process of $\mathrm{Fe} 0-\mathrm{BC}$

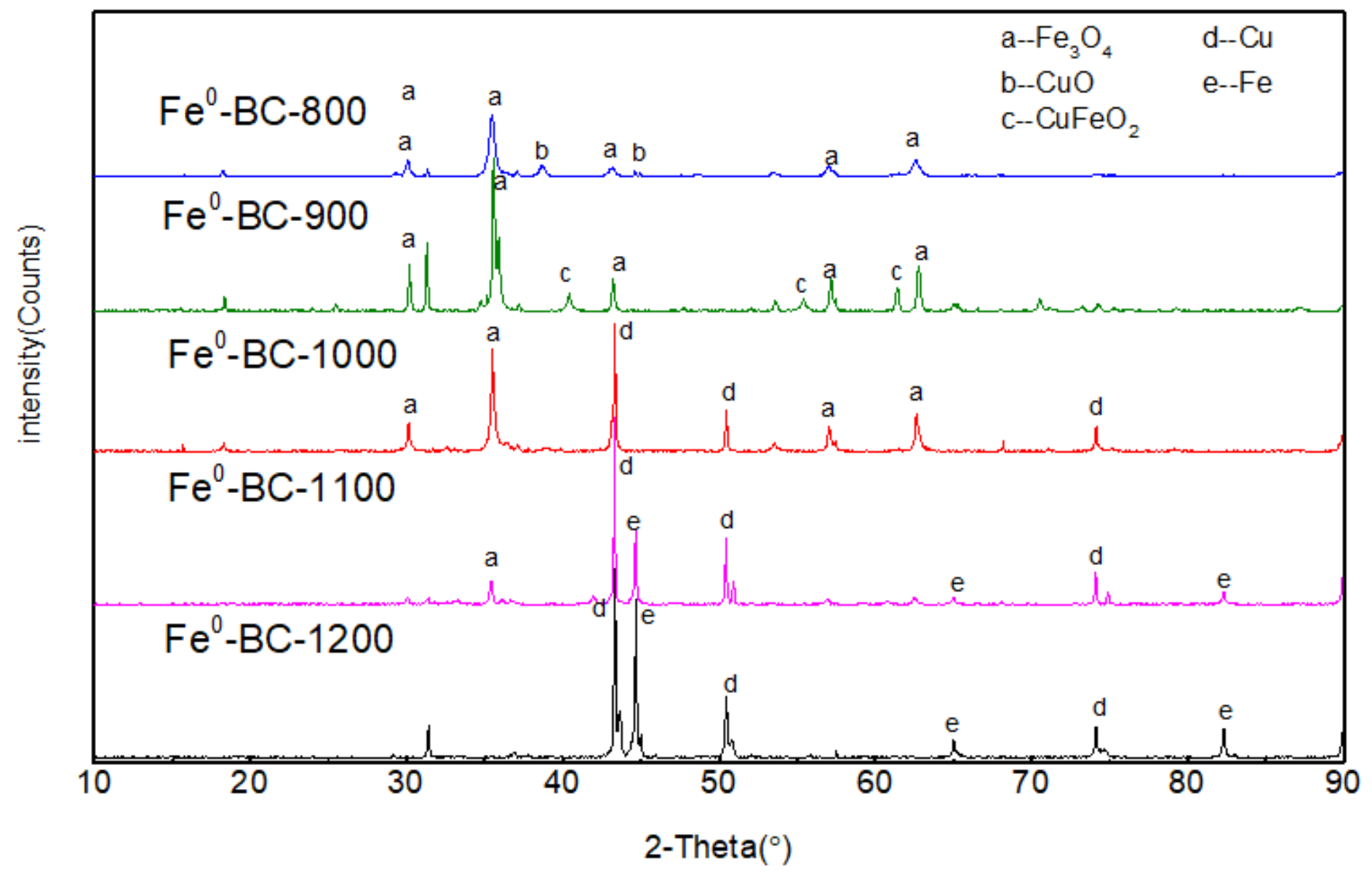

Figure 3

XRD patterns of $\mathrm{Fe} 0-\mathrm{BC}$

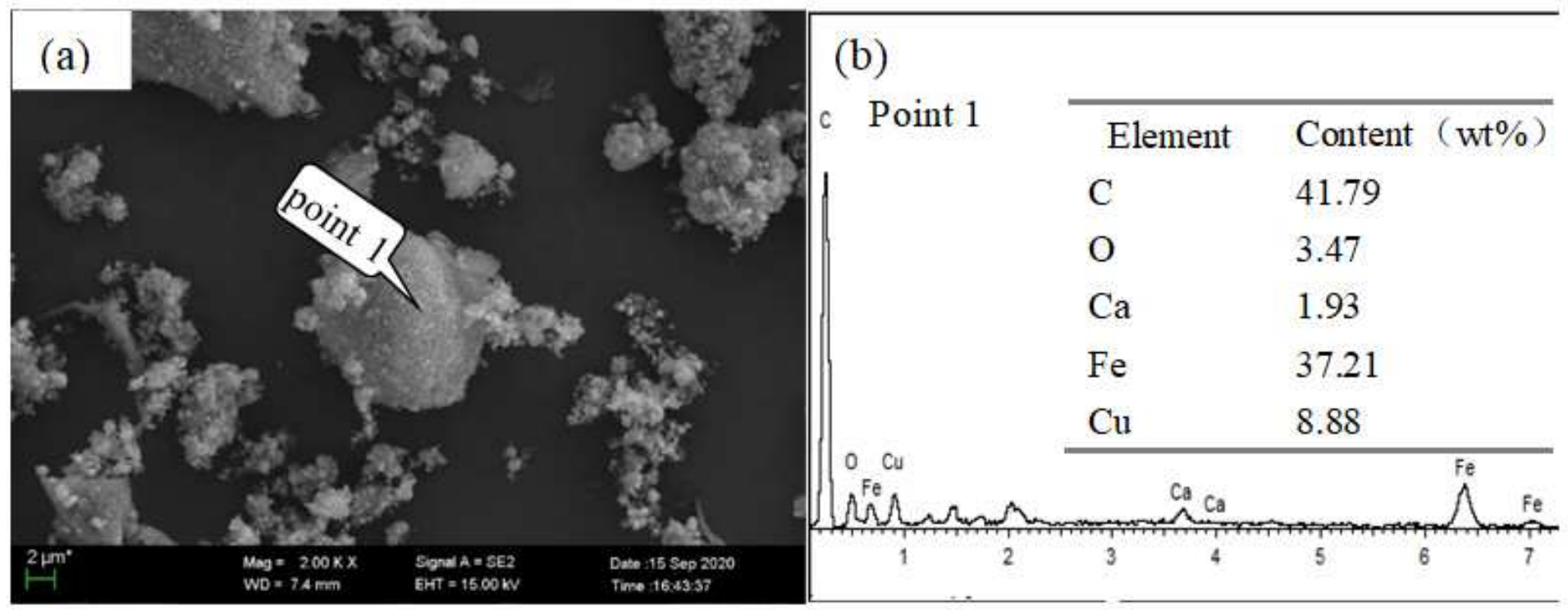

Figure 4 
SEM image and EDS results of Fe0-BC-1200

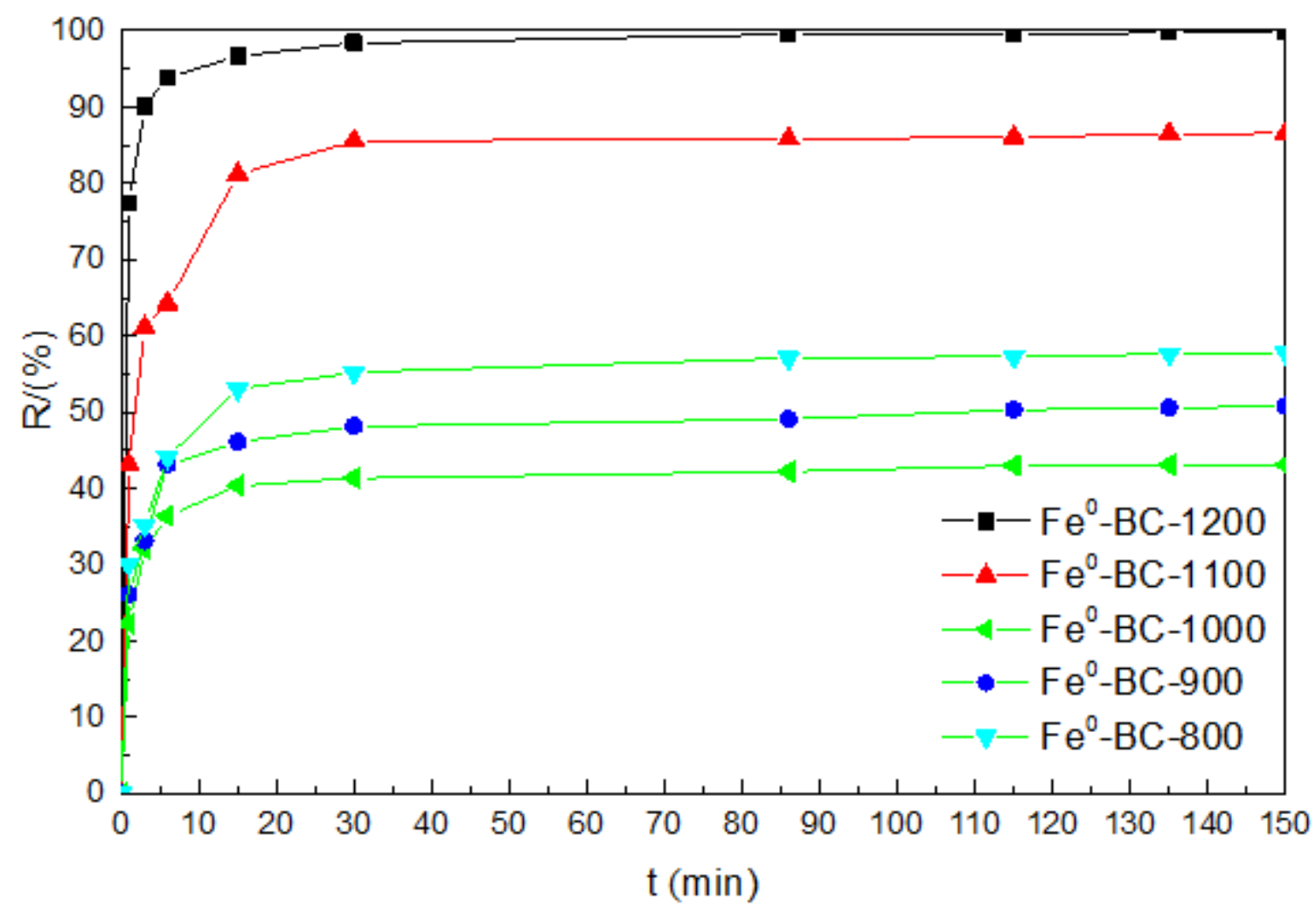

Figure 5

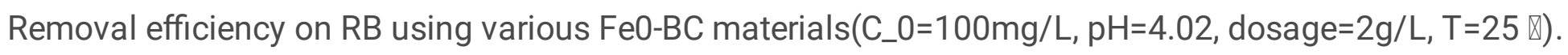




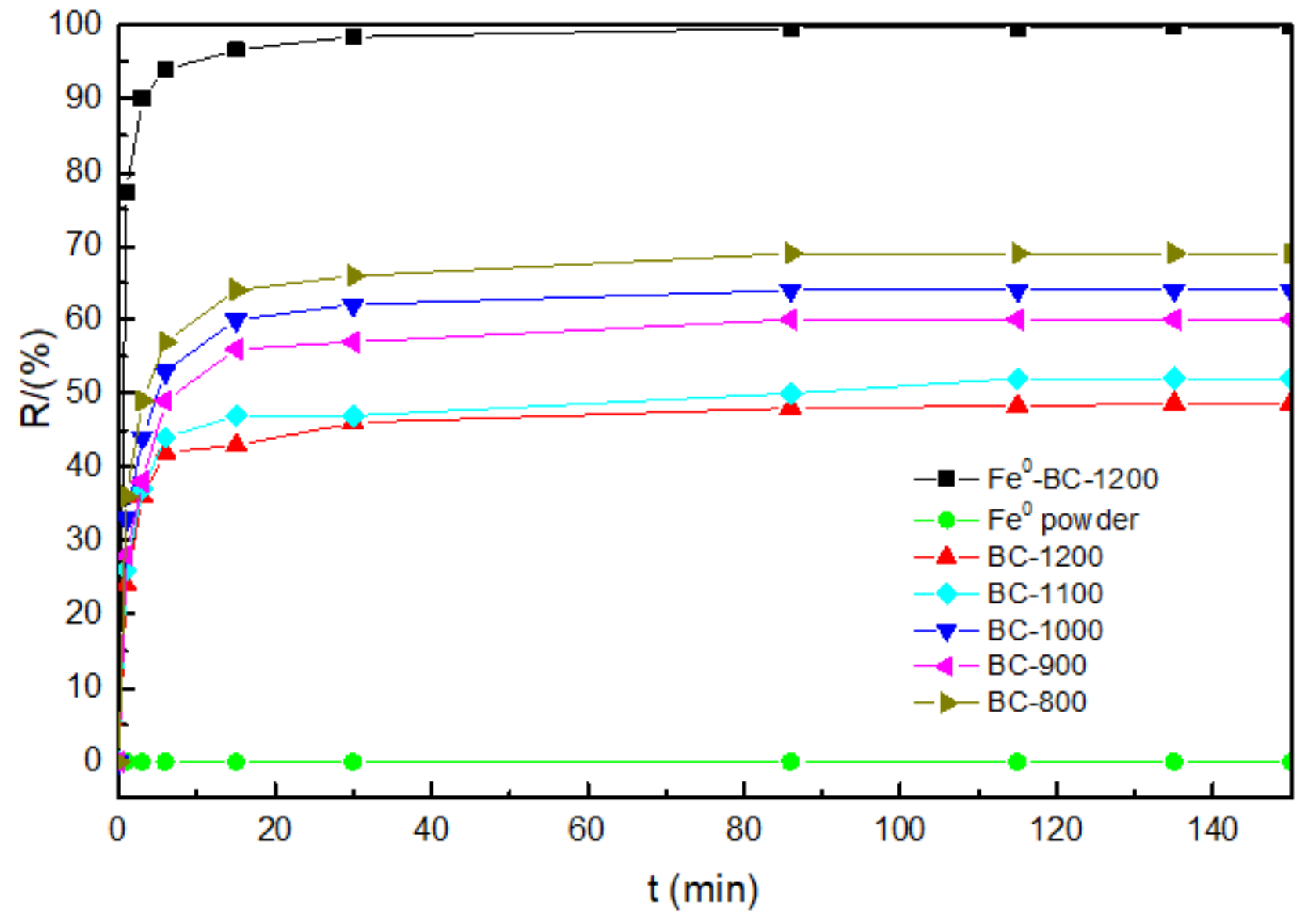

Figure 6

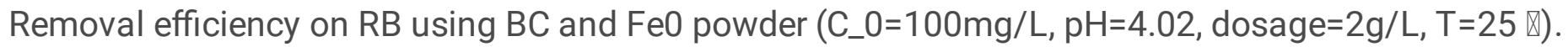



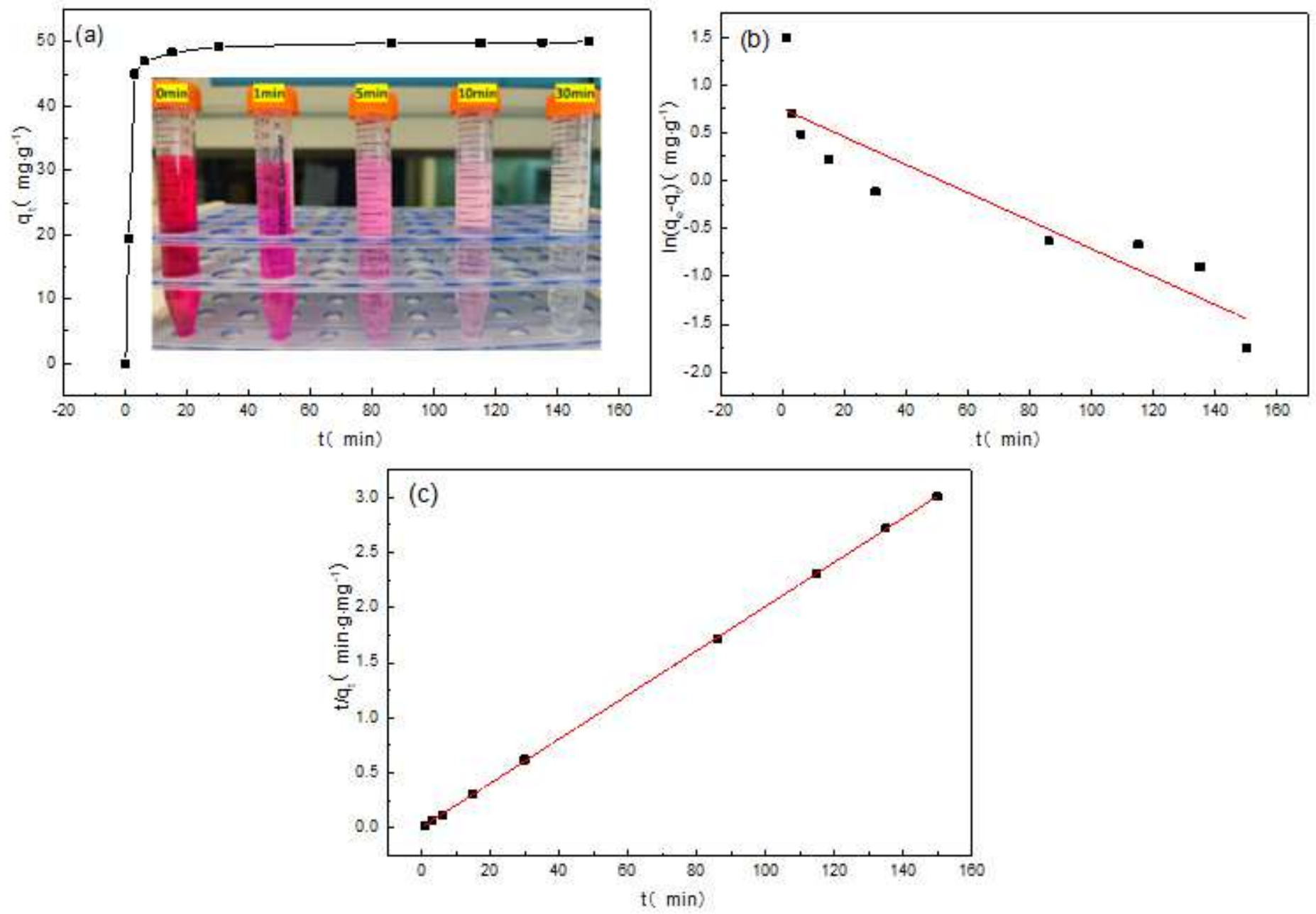

Figure 7

Removal capacities of RB on Fe0-BC-1200 with time(a), kinetic liner plots of pseudo-first-order model (b)

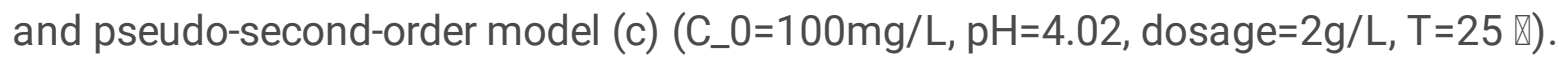




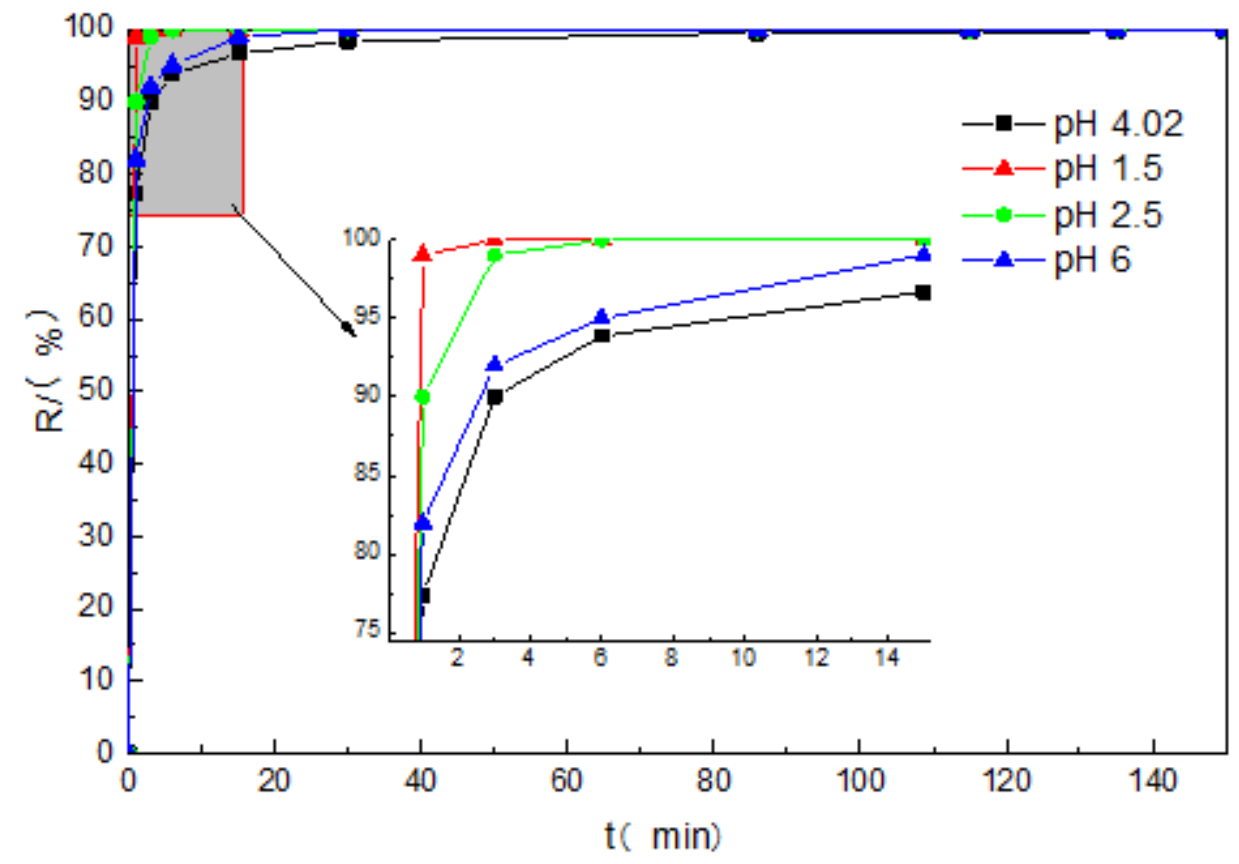

Figure 8

Effects of initial solution $\mathrm{pH}$ on removal efficiency by Fe0-BC-1200 (C_0 $0100 \mathrm{mg} / \mathrm{L}$, dosage $=2 \mathrm{~g} / \mathrm{L}, \mathrm{T}=25$ 区).

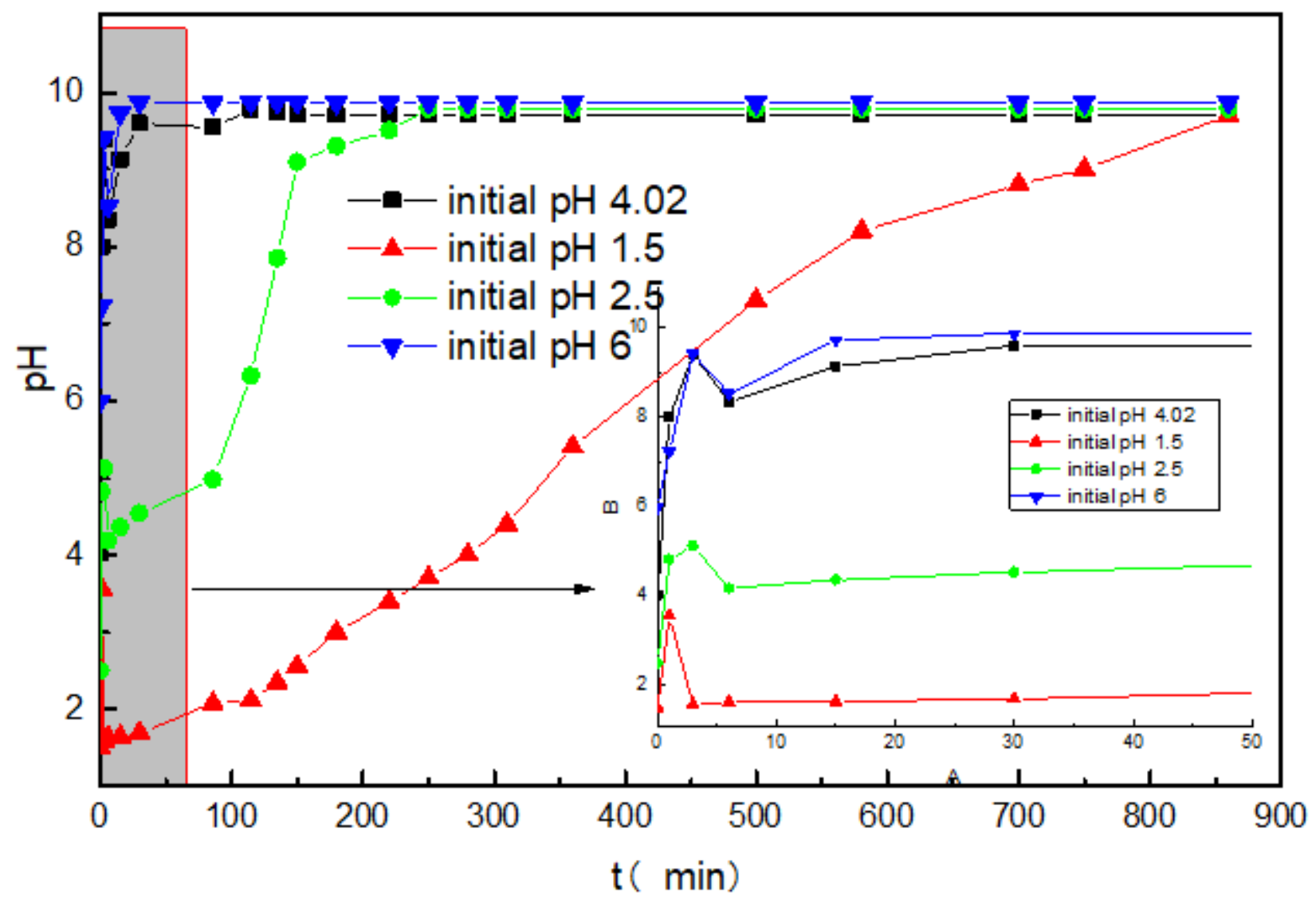


Figure 9

Solution $\mathrm{pH}$ at different selected sample time $\left(\mathrm{C} \_0=100 \mathrm{mg} / \mathrm{L}\right.$, dosage $\left.=2 \mathrm{~g} / \mathrm{L}, \mathrm{T}=25 \mathrm{Q}\right)$.
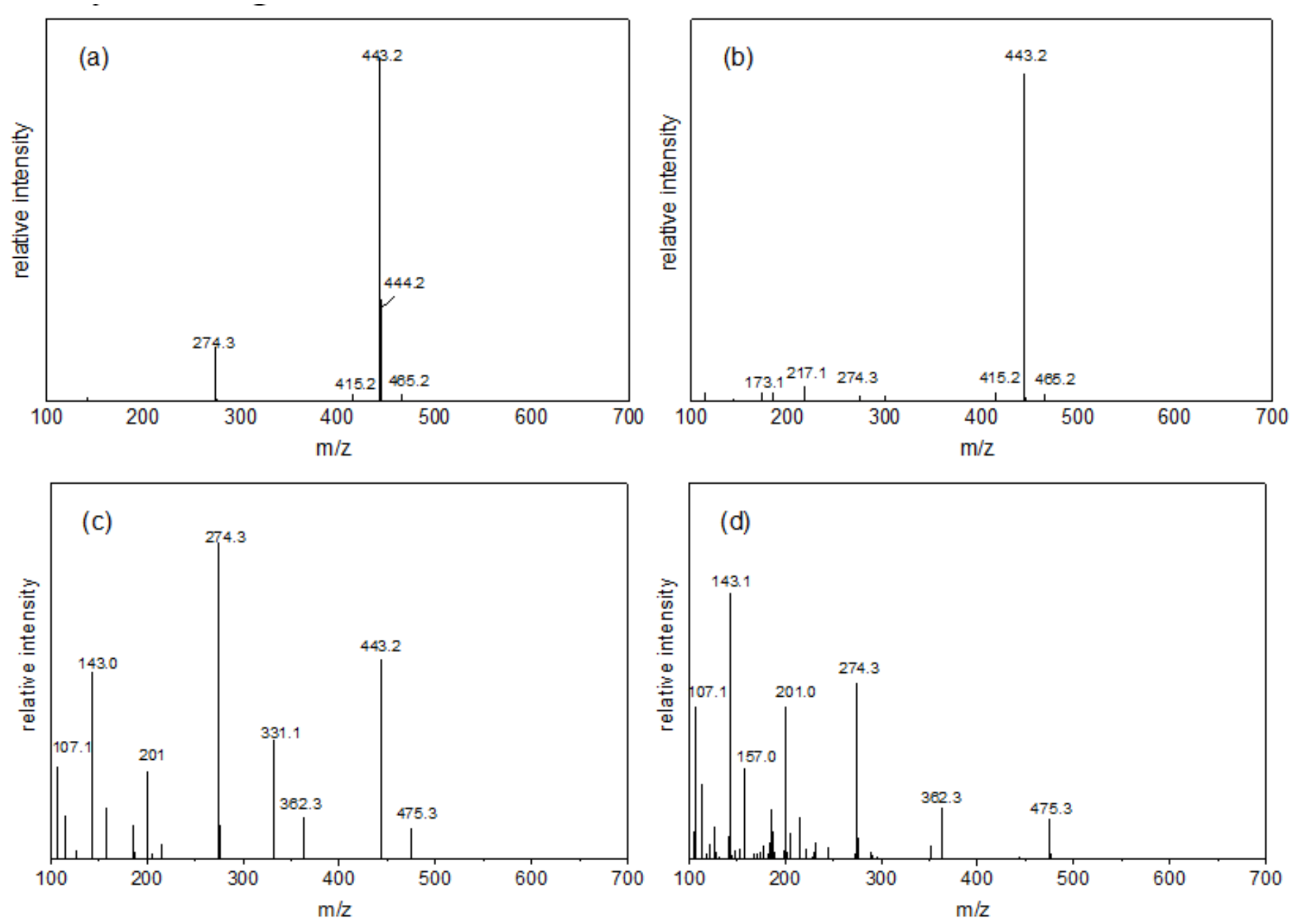

Figure 10

Mass spectra of RB at different reaction time: (a) $0 \mathrm{~min}$, (b) $1 \mathrm{~min}$, (c) $15 \mathrm{~min}$, (d) $30 \mathrm{~min}$. 


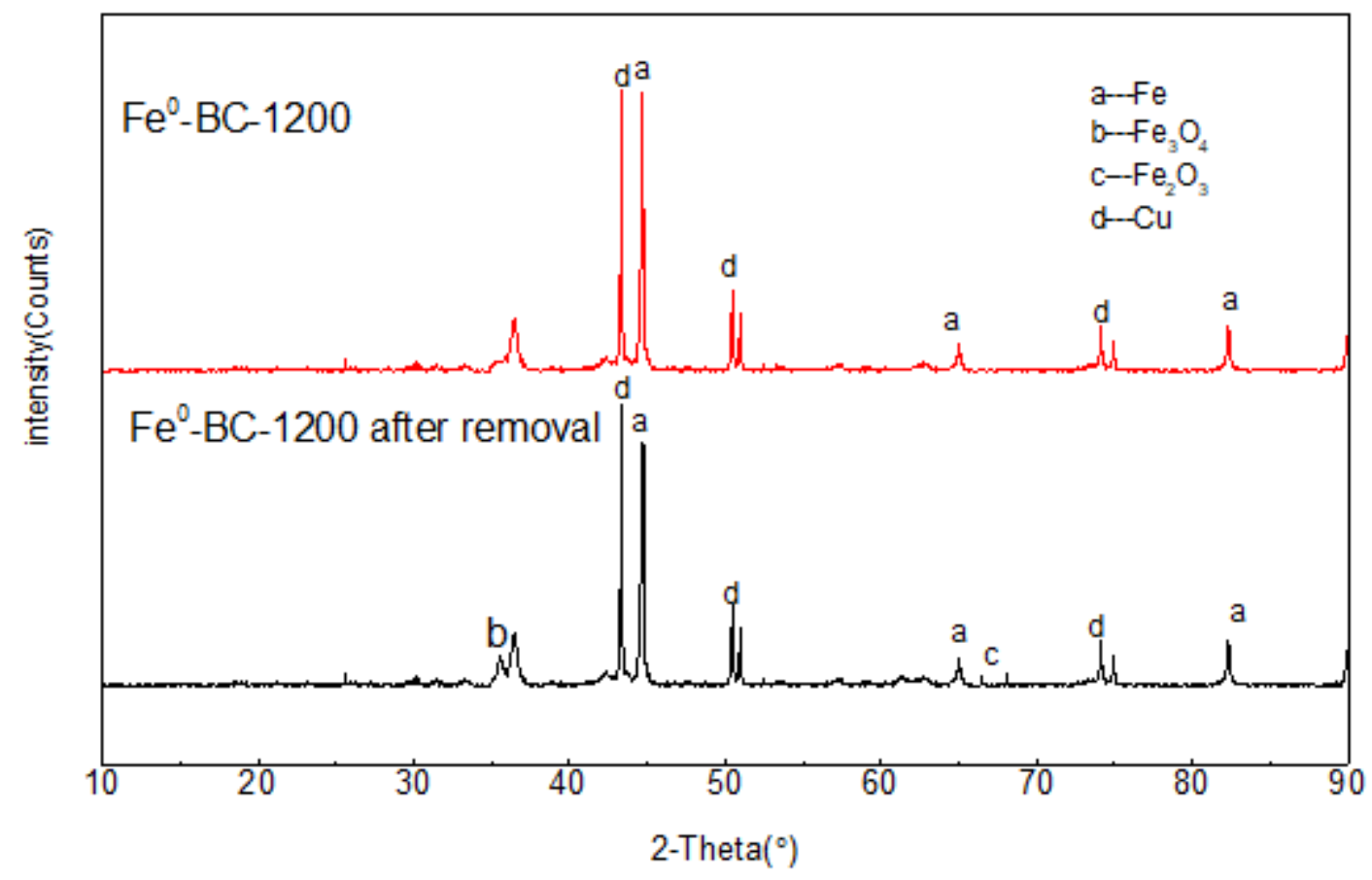

Figure 11

XRD patterns of Fe0-BC-1200 before and after removal of RB

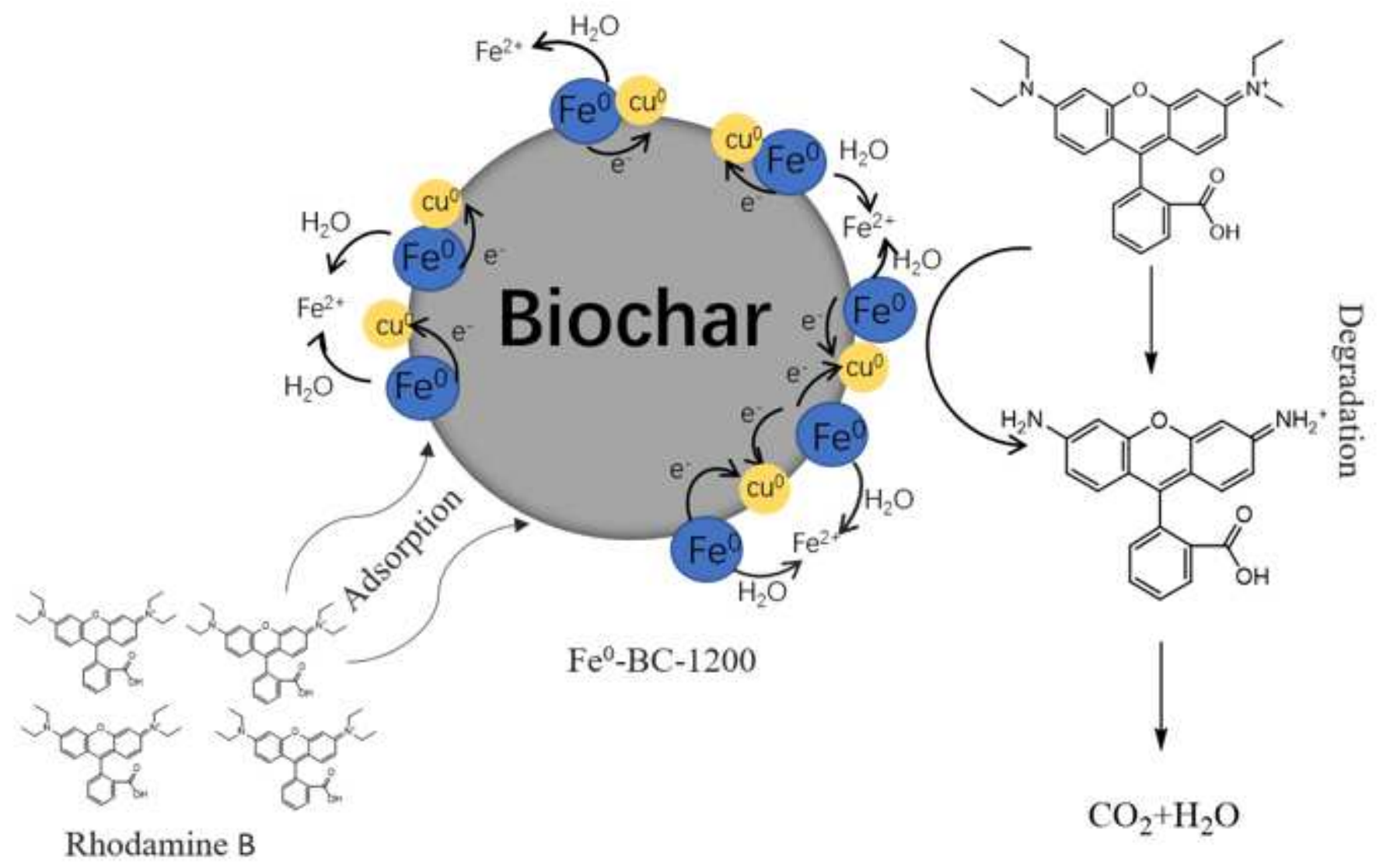

Figure 12 
Mechanism diagram of RB removal by Fe0-BC-1200. 